\title{
ACRITARCH BIOSTRATIGRAPHY OF THE LOWER- MIDDLE CAMBRIAN BOUNDARY IN THE IBERIAN CHAINS, PROVINCE OF SORIA, NORTHEASTERN SPAIN
}

\author{
Teodoro PALACIOS' and Malgorzata MOCZYDKOWSKA ${ }^{2}$ \\ ' Área Paleontología. Facultad de Ciencias. Universidad de Extremadura. E-06071 Badajoz. Spain. E-mail: \\ medrano@guadiana.unex.es \\ 2 Micropalaeontology. Institute of Earth Sciences. University of Uppsala. Norbyvägen 22. S-752 36 \\ Uppsala. Sweden. E-mail: malgo.vidal@pal.uu.se
}

Palacios, T. and MoczydXowska, M. 1998. Acritarch biostratigraphy of the Lower-Middle Cambrian boundary in the Iberian Chains, province of Soria, northeastern Spain. [Bioestratigrafía de acritarcos del límite Cámbrico Inferior-Cámbrico Medio en las Cadenas Ibéricas, provincia de Soria, noreste de España.]. Revista Española de Paleontología, no extr. Homenaje al Prof. Gonzalo Vidal, 65-82. ISSN 0213-6937.

\begin{abstract}
The Lower and Middle Cambrian age acritarch assemblages are reported from a continuous succession of the siliciclastic-carbonate Ribota, Huérmeda and Daroca Formations in the Iberian Chains, northeastern Spain. One new genus and four new species are described, one of them in open nomenclature. The microfossil assemblages allow to recognize the Lower Cambrian Heliosphaeridium dissimilare-Skiagia ciliosa and Volkovia dentiferaLiepaina plana acritarch zones, and to discuss an informal lowermost Middle Cambrian acritarch zone. These zones correspond respectively to the Holmia kjerulfi, Protolenus and Acadoparadoxides oelandicus trilobite zones, identified in the Acado-Baltic faunal province. The first appearance of Eliasum Ilaniscum, Celtiberium dedalinum and Retisphaeridium dichamerum, which are age-diagnostic for the Middle Cambrian, in the upper Daroca Formation is interpreted to point the Lower-Middle Cambrian boundary. This stratigraphic level underlies the previously established trilobite-based boundary. The depositional environments and biostratigraphy of the concerned strata are discussed.
\end{abstract}

Key words: Acritarchs, biozonation, Lower Cambrian-Middle Cambrian, Iberian Chains, Northeastern Spain.

\section{RESUMEN}

Se refieren varias asociaciones de acritarcos del Cámbrico Inferior y Cambrico Medio en las Cadenas Ibéricas, España nororiental, a lo largo de una sucesión continua de materiales carbonatados y siliciclásticos de las formaciones Ribota, Huérmeda y Daroca. Se describe un género nuevo y cuatro especies, una de ellas en nomenclatura abierta. Las asociaciones de microfósiles permiten reconocer las biozonas de Heliosphaeridium dissimilare-Skiagia ciliosa y Volkovia dentifera-Liepaina plana del Cámbrico Inferior y una asociación, todavía no formalizada, del Cámbrico Medio. Las zonas del Cámbrico inferior se corresponden con las de trilobites de Holmia kjerulfi, Protolenus y la asociación del Cámbrico Medio con la zona de Acadoparadoxides oelandicus, identificadas en la provincia Acado-Báltica. Se propone como indicativo del límite Cámbrico Inferior-Cámbrico Medio la primera aparición en la parte superior de la Formación Daroca, de las especies Eliasum Ilaniscum, Celtiberium dedalinum y Retisphaeridium dichamerum, diagnósticas del Cámbrico Medio. Este nivel estratigráfico se sitúa por debajo el límite propuesto anteriormente mediante trilobites. Por ultimo se discuten la biostratigrafía de los estratos que contienen las asociaciones de acritarcos y el ambiente de depósito, este último con base en el registro continuo de palinofacies.

Palabras clave: Acritarcos, biozonación, Cámbrico Inferior-Cámbrico Medio, Cadenas Ibéricas, Noreste de España.

\section{INTRODUCTION}

The Lower and Middle Cambrian sedimentary rocks are widespread and well exposed in the Iberian Peninsula
(Fig. 1), and have been intensively studied for the fossil content and biostratigraphy. They represent detrital and carbonate successions that are unevenly tectonically deformed in different regions, being thermally altered up 


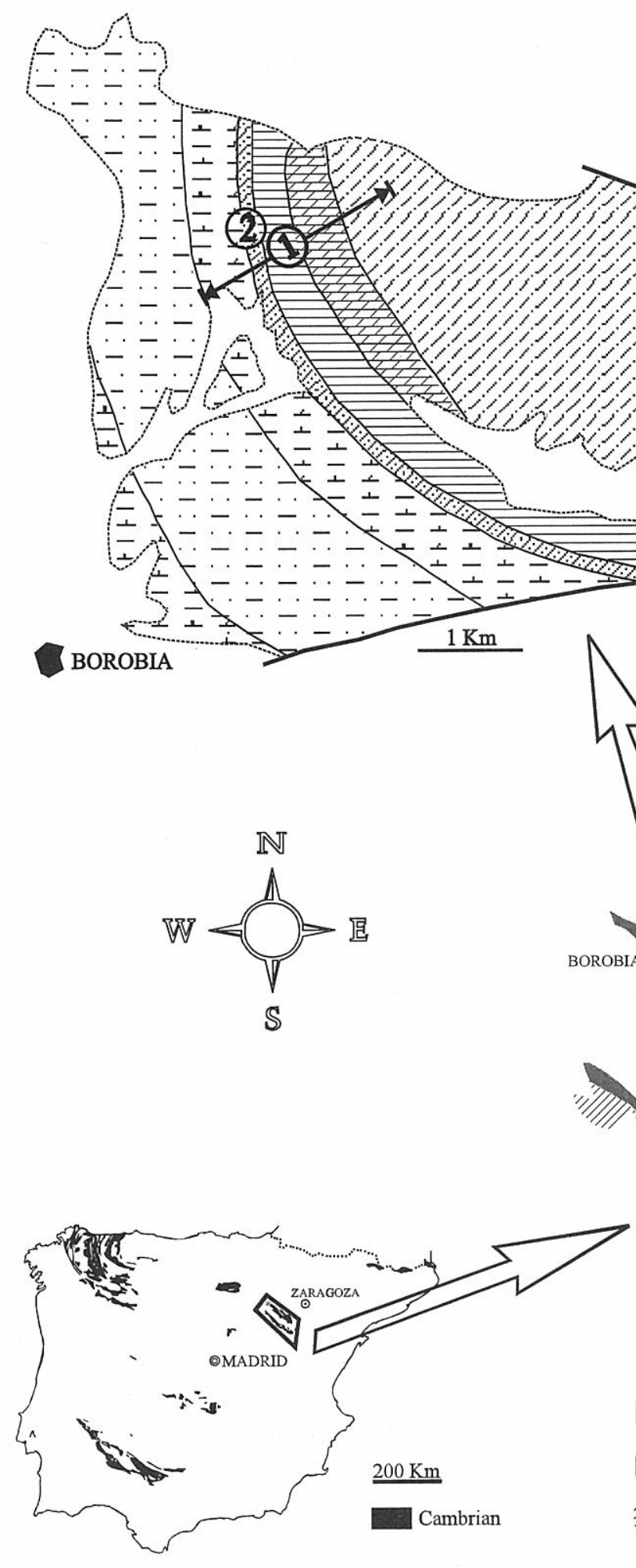

\section{MIDDLE -UPPER CAMBRIAN \\ Acón Group}

$\therefore-$ Sanstones and shales

MIDDLE CAMBRIAN

Valdemiedes, Mansilla \& Murero Formations

$\square \pm$ Shales, dolostones \& limestones

\section{LOWER-MIDDLE CAMBRIAN \\ Daroca Formation}

\% Arkosic sandstones and shales

LOWER CAMBRIAN

Huérmeda Formation

Shales and fine sandstones

Ribota Formation

Dolostones and shales

Embid \& Jalón Formations

Sandstones, shales and dolomitic marls

(1) BO1 Section (2) BO1A Section

Normal contact Discordant Fault

Figure 1. Simplified geological map of the Iberian Chains showing the detailed location of investigated sections. (After Esnaola Gómez and Martín Fernández, 1972, and Hernández Samaniego et al., 1980.)

to low grade of metamorphism. Despite of this, the sedimentary structures, spacial facies distribution and the fossils, both with hard skeletons and organic-walled, are well preserved and serve as an excellent field for depositional, environmental and palaeobiological investigations. 
The biostratigraphic subdivision of the Lower and Middle Cambrian in Iberia was formalized by Sdzuy (1968, 1971 a, b, 1972), Liñán (1984), Liñán, Perejón and Sdzuy (1993), and compiled by Liñán, Perejon et al. (1996) and Sdzuy et al. (1996). Among the other areas, the Iberian Chains are known for a wide extent of clastic shelf and carbonate platform deposits yielding faunas that have been used to define the Lower Cambrian regional stages.

Some organic-walled microfossils of planktonic, presumably algal and of other unknown protistan biological affinities referred to an informal group of Acritarcha Evitt, 1963, were abundantly recovered from the Cambrian strata in the Iberian Peninsula (Cramer and Díez Cramer, 1972; Fombella, 1977, 1978, 1979; Mette, 1989; Palacios and Vidal, 1992; Palacios, 1993; Vidal et al., 1994). The acritarch-based biostratigraphy of the Cambrian (Martin and Dean, 1981, 1988; Vidal, 1981, 1985; Volkova et al., 1983; Welsch, 1986; Di Milia et al., 1989; MoczydXowska, 1991, in press; Vidal and Peel, 1993; Vidal and MoczydYowska, 1996; Zang, 1992), and in general of the lower Palaeozoic (see for a recent review Molyneux et al., 1996) is in a great progress, being applied to successions in the palaeocontinents of Baltica, East Avalonia, Siberia, Laurentia and Gondwana. We report herein on the occurrence of acritarchs, including trhee new species, in the Borobia area, Province of Soria in the Iberian Chains, their taxonomy (with additional observations on material from the Zafra area in SW Spain), depositional environments and the biostratigraphy of the Lower-Middle Cambrian strata. The primary report on these acritarchs was earlier mentioned by Gámez et al. (1991). The stratigraphic level for the Lower-Middle Cambrian boundary is re-evaluated in the Iberian Chains and it is suggested to be placed within the Daroca Formation, in difference to the previously proposed position in the overlying Valdemiedes Formation.

\section{GEOLOGICAL SETTING}

The Lower-Upper Cambrian siliciclastic-carbonate successions in the Iberian Chains overlie Neoproterozoic turbiditic strata with an angular unconformity which reflects the Cadomian phase of the Pan-African Orogeny (Vidal et al., 1994). Neoproterozoic rocks, consisting of shale, sandstone, chert and oncolitic carbonate and referred to the Paracuellos Group are deformed and metamorphosed under low grade metamorphic conditions. They yielded an ichnofossil assemblage similar to that from the central part of Iberia and being indicative of the Vendian age (Liñán and Tejero, 1988). The Cambrian strata are transitionally overlain by Tremadocian shale and then the Armorican Quartzite (Liñán, Perejón et al., 1996). They were affected by several tectonic episodes during the Variscan and Alpine orogenies resulting in chain folding and development of schistosity.

The Lower-Middle Cambrian successions exceed
2,300 $\mathrm{m}$ in thickness and comprise, in the ascending order, the Bámbola, Embid, Jalón, Ribota, Huérmeda, Daroca, Valdemiedes, Mansilla and Murero formations and Acón Group (Gozalo, 1995). Their biostratigraphy is established on the occurrence of trilobites (Lotze, 1961; Sdzuy, 1961; Sdzuy, 1971 a, b; for a recent review see Liñán, Perejón and Sdzuy, 1993 and Liñán, Perejón et al., 1996), trace fossils (Valenzuela et al., 1990), and more recently acritarchs (Gámez et al., 1991; Liñán, Villas et al., 1996; and present study). The Upper Cambrian detrital rocks, approaching in thickness almost $1,000 \mathrm{~m}$ (Liñán, Villas et al., 1996), are out of scope of the present paper.

The basal portion of the Cambrian succession in the study area, consisting of alternating sandstone and shale with intercalations of carbonates of the Jalón Formation form a sequence of prograding nearshore to shallow shelf depositional facies. The transitionally succeding dolomite interbedded with shale and marl in the Ribota Formation accumulated in a stable carbonate platform (Alvaro et al., 1995), and in more offshore environments (in the upper part of the formation; Fig. 2). These sediments gradually pass into alternating shale and sandstone of the Huérmeda Formation deposited in a deeper distal portion of the platform. Similar lithology is observed in the lower part of the Daroca Formation and thus the sedimentary conditions. The arkosic sandstone interbeds, ranging from few centimetres to 9 meters in thickness (Figs. 2, 4; Gámez et al., 1991) occur at several levels within the succession of alternating arkosic sandstone and shale in the upper Daroca Formation. The increased occurrence of current and wave sedimentary structures in the arkosic intervals indicate the high energy nearshore depositional conditions. Abundant and probably reworked specimens of trilobites attributed to the genus Strenuaeva and Pseudolenus (Liñán, pers. comm.) and unidentified brachiopods occur in the arkosic beds with planar cross stratification in the upper Daroca Formation (Fig. 4). The upper Daroca succession was interpreted to correspond to the Daroca regression and correlated with the Hawke Bay regression in Laurentia (Liñán and Gámez-Vintaned, 1993). These strata might be interpreted to record a shallowing up episode in the depositional basin but without an emergence or sedimentary break (in contrast to the Hawke Bay regression, Palmer and James, 1980). The basin was stabilized shortly after the deposition of the arkosic sandstone and a clastic-carbonate platform persisted, with monotonous accumulation of marl, shale and sandstone, throughout the deposition times of the succeeding Valdemiedes to Murero Formations. Formerly, the Valdemiedes Formation have been considered to record a terminal Early Cambrian extinction event (Liñán, Fernández-Nieto et al., 1993; Liñán, Villas et al., 1996).

The geological successions dealt with this study are located at the border of Soria and Zaragoza Provinces. The fossil record from the two localities include poorly preserved trilobites and inarticulate brachiopods (Figs. 2, 4; Liñán, pers. comm.), and here reported acritarchs (Figs. 3, 5). 


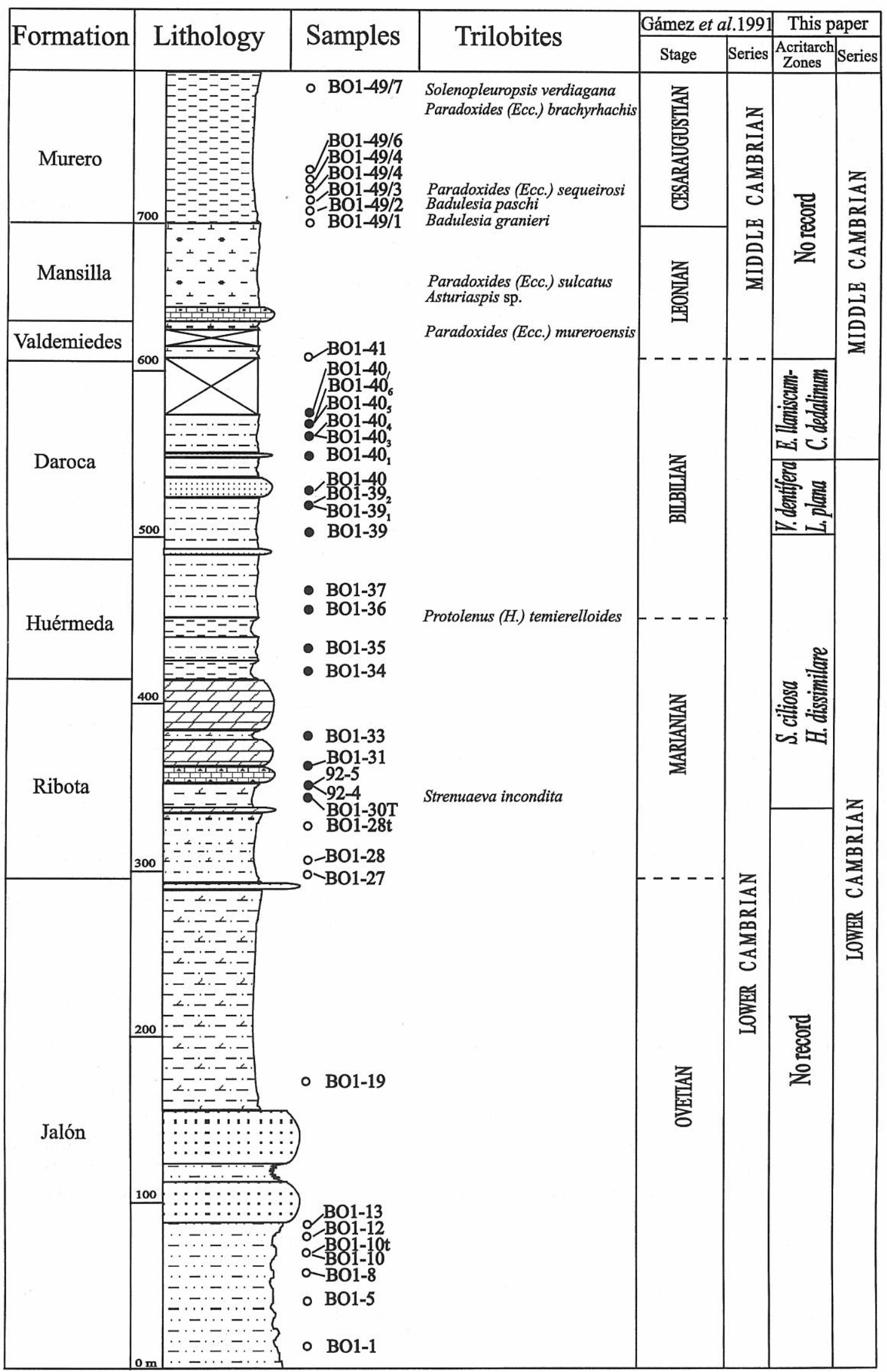

Figure 2. The Borobia 1 section showing the stratigraphic position of the acritarch samples and occurrence of trilobites. Lithostratigraphy and faunal biostratigraphy is according to Gámez et al., 1991, Liñán, et al., 1992, and Álvaro and Liñán, 1997. The alternative level for the Lower-Middle Cambrian boundary is proposed on the basis of the acritarch occurrences. The Lower-Middle Cambrian boundary recognized by acritarchs is shown in the rigtht column. 


\begin{tabular}{|c|c|c|c|c|c|c|c|c|c|c|c|c|c|c|c|c|c|c|c|c|c|c|c|c|c|c|}
\hline \multicolumn{2}{|c|}{ 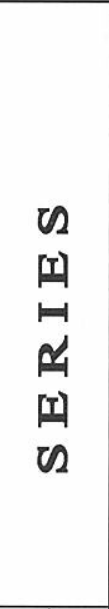 } & 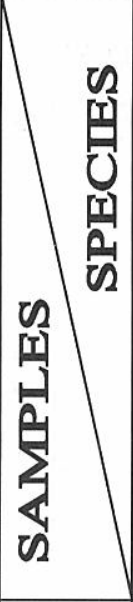 & 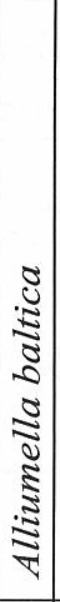 & 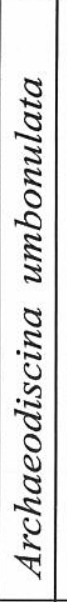 & 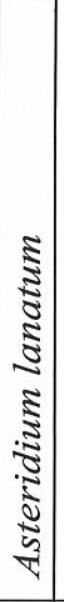 & 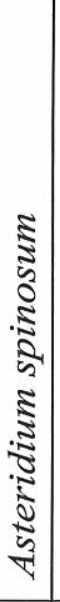 & 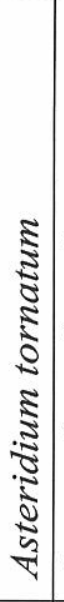 & 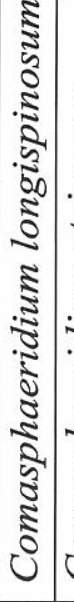 & 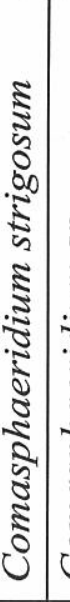 & 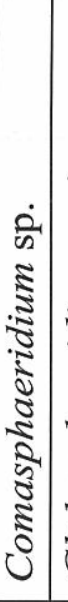 & 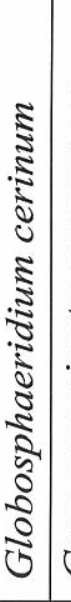 & 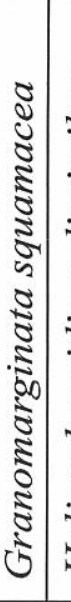 & 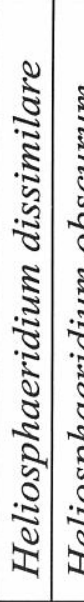 & 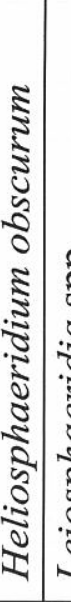 & 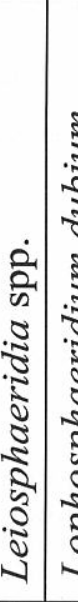 & 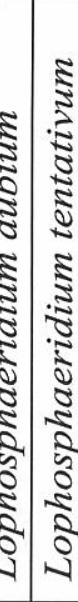 & 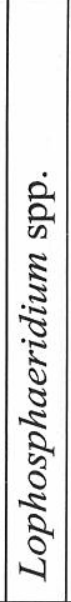 & 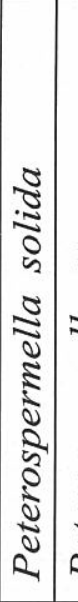 & 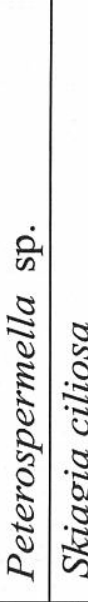 & 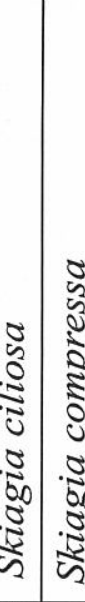 & 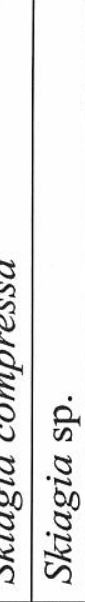 & 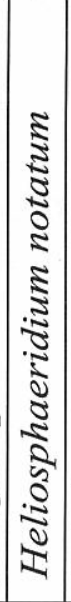 & 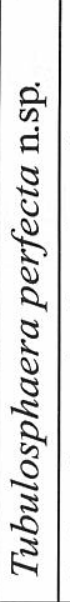 & 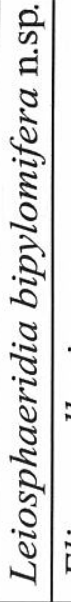 & 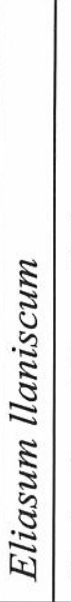 & 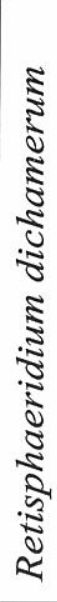 \\
\hline \multirow{19}{*}{$\begin{array}{l}\mathrm{Z} \\
4 \\
H \\
\alpha \\
M \\
M \\
3 \\
4 \\
0\end{array}$} & \multirow{6}{*}{ 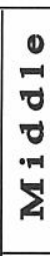 } & BO1-40, & & & & & & & & & & & & & "s & & 0 & & & है" & $\approx n$ & - & & & & 0 \\
\hline & & BO1-40 & & & & 0 & & & & & & 0 & & & 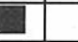 & & & & & & $\square$ & $\bullet$ & & & & \\
\hline & & BO1-40 & & & & & & & & & & 0 & & & 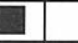 & & & & & & $\delta_{0}^{20}$ & 0 & & & & \\
\hline & & B01-40 & & & & & & & & & & & & & $\square$ & & & & & & & 0 & & & & \\
\hline & & BO1-40 & & & & & & & & 0 & & & & & $\square$ & & & & & & & & & & 0 & \\
\hline & & B01-40, & & & & & & & & & & & & \begin{tabular}{l|l}
0 & 5 \\
\end{tabular} & $\bar{\square}$ & & & & & & & 0 & & & 0 & \\
\hline & \multirow{13}{*}{$\begin{array}{l}H \\
0 \\
B \\
0 \\
H\end{array}$} & B01-40 & & & 0 & 0 & 0 & & & & & & & \begin{tabular}{l|l}
0 & $\varepsilon$ \\
\end{tabular} & 3 & & & & \begin{tabular}{l|l}
0 & 0 \\
\end{tabular} & 0 & & 0 & & & & \\
\hline & & BO1-39, & & & 0 & 0 & & & & & & & & & & & & & & & & 0 & & & & \\
\hline & & B01-39, & 0 & & & 0 & & & & & & \begin{tabular}{l|l}
0 & \\
\end{tabular} & - & & $\square$ & & & & & o & & 0 & 0 & 0 & & \\
\hline & & B01-39 & & & & 0 & 0 & & & & & & & & 0 & & & & & 囯 & & & & & & \\
\hline & & B01-37 & & & & & & & & & & & & & \begin{tabular}{l|l} 
\\
\end{tabular} & $\begin{array}{l}0 \\
0\end{array}$ & & & & 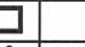 & & & & & & \\
\hline & & B01-36 & & & & & 0 & & & & 0 & & 0 & & 은 & & & & & \begin{tabular}{c|c}
0 & 0 \\
\end{tabular} & \begin{tabular}{l|l}
0 & $\varepsilon^{n}$
\end{tabular} & & & & & \\
\hline & & BO1-35 & & & & & & & & & & & & & $\square$ & & & & & 7 & & & & & & \\
\hline & & B01-34 & 0 & & & 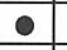 & & & & 0 & 0 & & \begin{tabular}{l|l}
0 & 0 \\
\end{tabular} & \begin{tabular}{l|l}
0 & 5 \\
\end{tabular} & $\square$ & & & & \begin{tabular}{l|l}
0 & $\xi^{\prime \prime}$ \\
\end{tabular} & 3 & $\varepsilon$ & & & & & \\
\hline & & B01-33 & & & & & & & & & & & & & & & & & & $\square$ & & & & & & \\
\hline & & B01-31 & & & & & & & & & 0 & & & & 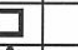 & 0 & & & & 0 & & & & & & \\
\hline & & $92-5$ & & $\varepsilon^{2}$ & 0 & & & & & & & \begin{tabular}{l|l}
0 & 5 \\
\end{tabular} & $\square$ & & 3 & 0 & 0 & \begin{tabular}{l|l}
0 & \\
\end{tabular} & \begin{tabular}{l|l}
0 & $\varepsilon^{\prime \prime}$
\end{tabular} & \begin{tabular}{l|l}
3 & 0 \\
\end{tabular} & $\xi_{0}^{\prime \prime}$ & & & & & \\
\hline & & $92-4$ & & $\square$ & & & & \begin{tabular}{l|l}
0 & $c$ \\
\end{tabular} & \begin{tabular}{l|l}
0 & $c$ \\
\end{tabular} & 0 & & \begin{tabular}{l|l}
0 & $c$ \\
\end{tabular} & 0 & & $\square$ & & 0 & \begin{tabular}{l|l}
0 & \\
\end{tabular} & \begin{tabular}{l|l} 
& $\varepsilon^{\prime}$
\end{tabular} & \begin{tabular}{l|l}
3 & 0 \\
\end{tabular} & \begin{tabular}{l|l|}
$n$ \\
\end{tabular} & & & & & \\
\hline & & B01-30T & \begin{tabular}{l|l}
0 \\
\end{tabular} & 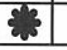 & & & 0 & & \begin{tabular}{l|l}
0 & $\mathrm{c}$ \\
\end{tabular} & 0 & & \begin{tabular}{l|l}
0 & L \\
\end{tabular} & \begin{tabular}{l|l}
$\square$ & 0 \\
\end{tabular} & \begin{tabular}{l|l} 
& $\varepsilon_{0}^{\prime \prime}$ \\
\end{tabular} & 3 & 0 & & & \begin{tabular}{l|l}
0 & $\varepsilon$ \\
\end{tabular} & \begin{tabular}{l|l} 
& 0 \\
\end{tabular} & $\varepsilon_{0}$ & & & & & \\
\hline
\end{tabular}

Figure 3. List of acritarch taxa and their distribution recorded in the Borobia 1 section.

\section{MATERIAL AND METHODS}

Fifty five samples from siliciclastic and carbonate successions exposed in two localities in the Borobia area (Fig. 1) were examined for the organic-walled microfossils. The section Borobia 1 exhibits almost $800 \mathrm{~m}$ thick pile of strata (Bo1, Fig. 2), and their covered upper part is complemented by the parallel section Borobia 1A (BolA, Fig. 4). The latter section is situated approximately $300 \mathrm{~m}$. towards NE from the Borobia I locality, and encompasses well-exposed strata of the upper part of the Daroca Formation, which were sampled in more details (Fig. 1). The microfossils were obtained from shales and marls of the Ribota Formation, and from shales, siltstones and arkosic sandstones of the Huérmeda and Daroca Formations. In contrary, all samples from the Jalón, Valdemiedes, and Murero Formations appeared to be barren.

The extraction of microfossils from rock samples, applying chemical digestion in concentrated inorganic acids, followed the method described by Vidal (1988).
The examination of organic residuum fixed in strew mounting was carried out using the Nikon light transmitted microscope with interference contrast. The state of preservation of microfossils is variable but generally good or satisfactory. Thin-walled acritarchs are usually well preserved and light brown in colour, whereas thick-walled leiosphaerids and tasmanitids are often corroded and display pseudomorphic imprints after pyrite crystals, being light to dark brown in colour. Coccoidal sheaths, presumable deriving from the sulphur-reducing bacteria, are abundant and show highly degraded granular surfaces. Acritarchs from the rock matrix of the arkosic sandstones in the Daroca Formation (samples Bo1A-5, 7, 9, 13 and 17) show variable states of preservation, and the rock matrix seem to include reworked specimens together with contemporaneous assemblages. Well preserved specimens, light in colour, co-occur with dark, poorly preserved specimens with corroded vesicle wall and broken ornamentation. All reworked specimens are of an Early Cambrian age. 


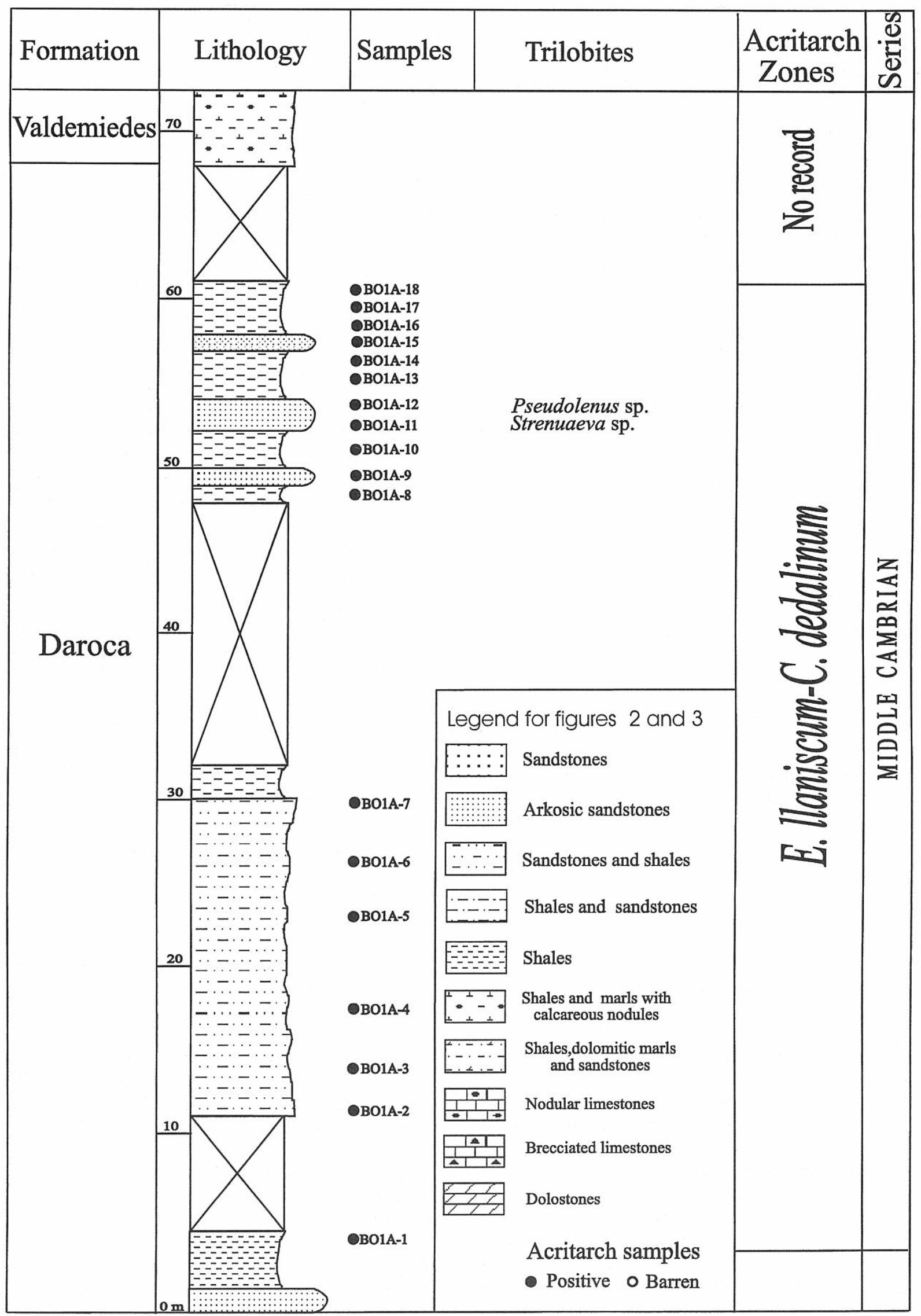

Figure 4. The Borobia 1A section, which is parallel and complementary to Borobia 1 section, showing the stratigraphic position of the acritarch samples and the occurrence of trilobite specimes. The Lower-Middle Cambrian boundary recognizes by acritarchs is shown in the rigtht column. 


\begin{tabular}{|c|c|c|c|c|c|c|c|c|c|c|c|c|c|c|c|c|c|c|c|c|c|c|c|c|}
\hline 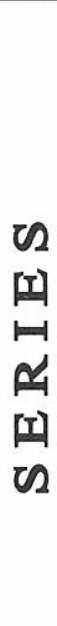 & 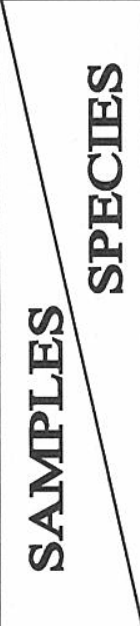 & 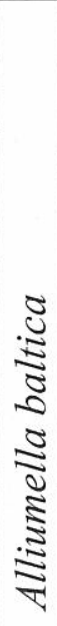 & 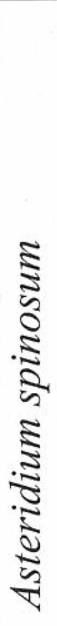 & 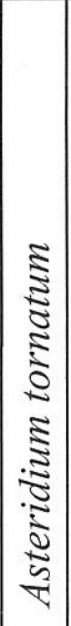 & 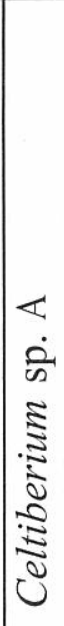 & 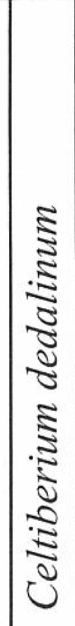 & 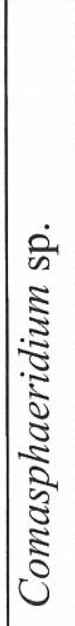 & 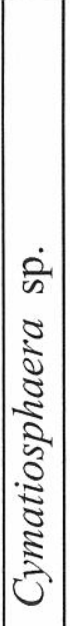 & 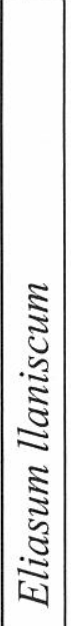 & 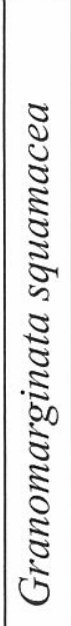 & 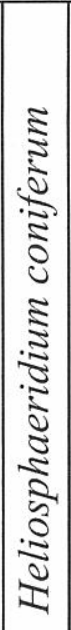 & 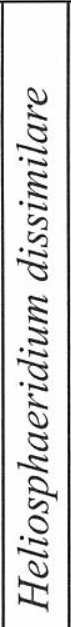 & 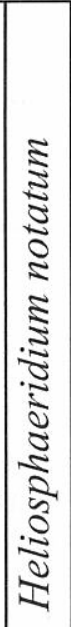 & 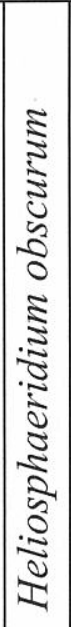 & 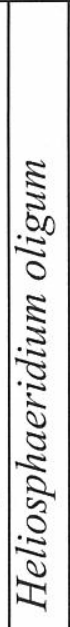 & 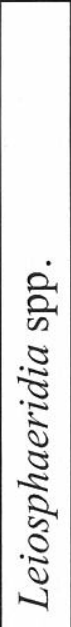 & 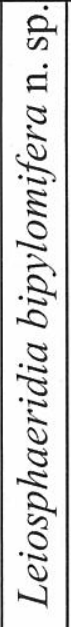 & 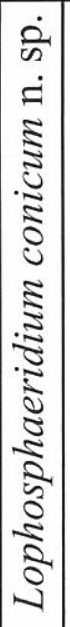 & 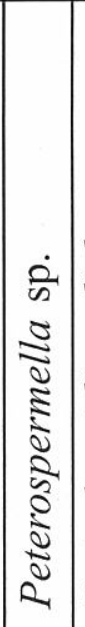 & 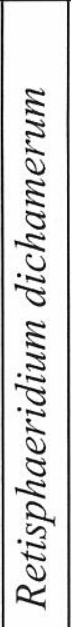 & 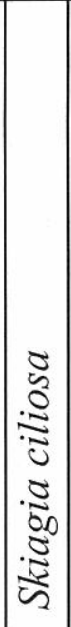 & 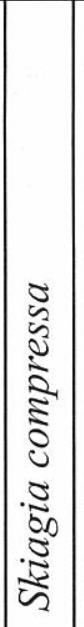 & 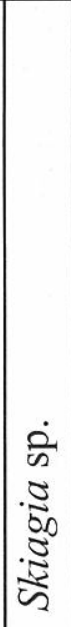 & 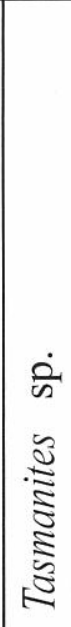 \\
\hline \multirow{9}{*}{$\begin{array}{l}q \\
\omega \\
\cdot-1 \\
H \\
0 \\
\text { a } \\
\omega \\
0\end{array}$} & BO1A-18 & & & & & & & & 0 & & & & & & & 0 & & & & & & & & \\
\hline & \begin{tabular}{|l|} 
BO1A-17 \\
\end{tabular} & & 0 & 0 & & & & & & & & & $\square$ & & & $\sum^{2}$ & & & & & Q & & $\square$ & \\
\hline & B01A-16 & & 0 & 0 & & & & & & & & & $\overline{0}$ & & & : & & & & & $\square$ & & $\square$ & 0 \\
\hline & B01A-15 & & & & & & & & & & & & $\square$ & & & 回 & & & & & 0 & & 인 & \\
\hline & B01A-14 & 0 & & & & & & & & & & & & & & $\varepsilon$ & & & & & 0 & & 0 & \\
\hline & \begin{tabular}{|l|} 
BO1A-13 \\
\end{tabular} & & & & & & & 0 & & & & & & & & $\varepsilon^{3}$ & & & & & $\xi^{2}$ & & $\varepsilon^{2}$ & \\
\hline & BO1A-12 & & & & & & & & & 0 & & & $\square$ & & & $\varepsilon_{0}^{2}$ & & & & & & & & \\
\hline & BO1A-11 & & & & & & & & & & & & $\square$ & & & $\varepsilon^{n}{ }^{n}$ & & & & & & & & \\
\hline & BO1A-10 & & & & & & & 0 & & & & & & & & $\square$ & 0 & & & & & & & \\
\hline \multirow{9}{*}{$\begin{array}{l}0 \\
-1 \\
0 \\
0 \\
0 \\
\dot{2}\end{array}$} & BO1A-9 & & & & 0 & & & & 0 & & & & $\square$ & & 0 & $\varepsilon_{\omega}^{n}$ & & 0 & & 0 & 国 & & 0 & 0 \\
\hline & BO1A-8 & & & & & & & & 0 & & & & - & & & $\varepsilon^{2}$ & & & & & $\square$ & & - & \\
\hline & BO1A-7 & & & & & & 0 & & & 0 & & & - & & & $\xi 3$ & & & & & $\sum^{\infty} \%$ & & $\varepsilon^{2}$ & 0 \\
\hline & BO1A-6 & & & & & & 0 & 0 & 0 & 0 & & $\square$ & $\square$ & & 0 & $\varepsilon^{n}{ }^{2}$ & & & & & $\bullet$ & 0 & $\square$ & \\
\hline & B01A-5 & 0 & & & & & 웅 & & & 0 & & & 0 & & & $\varepsilon^{n} \%$ & & & & & $\square$ & & $\square$ & \\
\hline & BO1A-4 & & & & & & & & & & & & $\square$ & & & $\varepsilon^{3}$ & & & & & & & & \\
\hline & B01A-3 & & 0 & 0 & & 0 & & & 0 & 0 & & & 0 & & & $\varepsilon^{\infty}$ & & & 0 & & $\square$ & & $\square$ & \\
\hline & B01A-2 & & & & & & & & 0 & & & & & 0 & & $\varepsilon^{2}{ }_{0}^{2}$ & & & & & & & & \\
\hline & BO1A-1 & & & & & & & & 0 & & 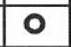 & & & 0 & & $\varepsilon_{0}^{2}$ & & & & & & & & \\
\hline
\end{tabular}

\section{Key to simbols}

o Very rare (1-2 counts) $\bigcirc$ Rare (3-5 counts) $\square$ Few (6-15 counts)

Abundant ( $>25$ counts)

Figure 5. List of acritarch taxa and their distribution recorded in the Borobia 1A section.

\section{MICROFOSSILS AND DEPOSITIONAL ENVIRONMENTS}

The microfossil assemblages from the Borobia area include a wide variety of taxa and comprise numerous species having well defined stratigraphic ranges and widespread palaeogeographic distributions. Four new species and one new genus are recognized, increasing the previously known Cambrian acritarch biodiversity. A number of specimens have been identified only to the generic level, such as Cymatiosphaera, Globosphaeridium, Pterospermella and Tasmanites, but they display a distinctive morphological diversity and add to the taxonomic richness of the Borobia microfossil association. The list of acritarch taxa and their relative succession in the geological records are shown in figures 3 and 5. The new species are described under Systematic palaeontology (see below; Figs. 6, 7), whereas species previously recognized and taxonomically re-evaluated are identified according to Fombella (1978), Volkova et al. (1983), MoczydYowska (1991, in press), Palacios and Vidal (1992), and Vidal and Peel (1993).

Most of the species belong to acanthomorphic, e.g. spiny acritarchs, which are attributed to the genera Asteridium, Heliosphaeridium and Skiagia (Figs. 8, 9). Heliosphaeridium dissimilare, $H$. notatum, $H$. obscurum, Skiagia ciliosa and S. compressa are abundant and their infraspecific variations and size limits conform to the previous occurrences. They are commonly recorded in Lower Cambrian strata and trespass into the lowermost Middle Cambrian. They are used with other concurrent age-diagnostic taxa in acritarch zonations (MoczydXowska, 1991, in press). H. coniferum, H. oligum and the species of Asteridium (A. lanatum, A. tornatum, A. spinosum) are less frequent but they occur in similar proportions with other species. The genera with conspicuous ornamentation, such as Alliumella, Celtiberium, Archaeodiscina, Multiplicisphaeridium, 
Lophosphaeridium, Retisphaeridium and Eliasum, though represented by single species within the association are biostratigraphically significant. Sphaeromorphic acritarchs are quantitatively dominant but lack biostratigraphic significance.

The stratigraphically lowest acritarch record in the Borobia succession derive from mudstone of the Ribota Formation in the interval containing trilobite Strenuaeva incondita Sdzuy, 1961 which is diagnostic for the Lower Cambrian Marianian regional Stage (Liñán, Perejón and Sdzuy, 1993; Figs. 2, 4). The acritarch assemblage is dominated by Heliosphaeridium dissimilare, Skiagia ciliosa and Archaeodiscina umbonulata, and other Early Cambrian species (Fig. 3) which display a remarkable morphological disparity. The assemblage occurs within a marine transgressive succession grading progressively from fine-grained clastic sediments (red-coloured sandstone and then shale) of the Jalón Formation into dolomite with microbial mats, oncolites and evaporites of the lower Ribota Formation (Gámez et al., 1991; Alvaro et al., 1995). The latter was deposited in littoral and marine nearshore environments. These strata subsequently pass into quite-water carbonate sediments with brachiopods, calcareous sponge spicules, echinoderms and trilobites in the upper Ribota Formation that are accumulated in sublittoral and more offshore environments. Samples from the upper Ribota Formation yielded few specimens of Skiagia but a considerable contents of particulate organic matter and coccoidal bacterial microfossils. This may suggest the existence of restricted circulation conditions in the sedimentary basin during the time of deposition of the upper Ribota Formation.

The microfossil assemblage from the Huérmeda Formation consists of 13 acritarch species (Figs. 2, 3), coccoidal bacterial and organic remains. The taxonomic diversity is slightly lower than in the lower Ribota Formation. The profuse accumulation of bacterial microfossils, organic matter and the presence of framboidal growth pseudomorphs of pyrite on the acritarch vesicles indicate a dynamic bacterial activity in the sediments and the prevalence of reduced conditions at the bottom zone of the depositional basin. The Huérmeda Formation comprises dark, kerogen-rich, laminated shale and alternation of shale and thin-bedded, fine-grained quartz sandstone. The lithology and organic facies of the formation and their succession within the entire marine sequence indicate a maximum flooding of the Early Cambrian transgression in the Borobia area.

Similar sedimentary conditions prevailed during the deposition of the lower part of the Daroca Formation. The same species as in the underlying strata are recorded, with a drastic decrease and even disappearance of the species of Skiagia, and three additional (e.g. H. notatum, Tubulosphaera perfecta n. sp. and Leiosphaeridia bipylomifera n. sp.) appear for the first time in this stratigraphic succession (Fig. 3). In the upper Daroca Formation is observed a shift in the depositional environments, with abundant reworked acritarchs from Huermeda Formation (Skiagia especies), that reflects the increase of environmental energy. The shallower-water lithofacies progressively migrated over older, relatively deep-water deposits. The migration of coarser lithofacies in the upper Daroca Formation ceased and subsequently a carbonate-detrital platform environments developed and continued throughout Middle Cambrian in the area.

The taxonomic composition of the acritarch assemblages in the upper Daroca Formation is identical to the lower part of the formation, with exception of the species (Celtiberium dedalinum, Eliasum llaniscum, Retisphaeridium dichamerum, Lophosphaeridium conicum n. sp. and Celtiberium sp. A) that appeared in the succession for the first time (Figs. 3, 5). C. dedalinum, E. llaniscum and $R$. dichamerum are of a particular stratigraphic significance because their lowermost appearance marks the base of Middle Cambrian (see below). The continuous succession of the same acritarch species throughout the Daroca Formation, despite of the conspicuous change in the depositional environments, seems to imply rather uninterrupted marine sedimentation. This also suggests largely facies independent distribution of acritarchs within shallow shelf depositional settings in Cambrian (Moczyd Xowska and Vidal, 1992; Palacios and Vidal, 1992; MoczydXows$\mathrm{ka}$, in press).

\section{BIOSTRATIGRAPHY OF THE BOROBIA SUCCESSION}

The global stratotype section for the Lower-Middle Cambrian boundary has not yet been established and various stratigraphic levels were recognized and/or proposed as standard candidates in different palaeogeographic areas (Bergström and Gee, 1985; Martin and Dean, 1988, Liñán, Fernández-Nieto et al., 1993; Liñán, Perejón et al., 1996; Young et al., 1994; Geyer and Landing, 1995; Landing, 1995; Zhuravlev, 1995; Sdzuy et al., 1996). The recognition of the regional boundaries is based on the occurrence of trilobite faunas that have mostly restricted geographic distribution and are often facies dependent. Their exact chronostratigraphic interregional correlation is thus uncertain (Geyer and Palmer, 1995; MoczydXowska et al., 1996; Palmer, 1996).

The new acritarch record from the Cambrian of the Iberian Chains provides an useful and complementary mean for the biostratigraphy and, in particular, for the correlation irrespective of the faunal bioprovinces. The acritarch association from the Borobia sections consists of numerous taxa having well-defined stratigraphic ranges that are recognized in various occurrences and bound to the trilobite zones. The succession of acritarchs provides an alternative biozonation and make possible recognition of biochrones that are time equivalent to the faunăl zones.

The Lower Cambrian rocks in the investigated area are sparsely fossiliferous. The Jalón Formation yielded only undiagnostic trace fossils. In other localities in the Iberian Chains poorly preserved trilobites from the 
formation, attributed to Dolerolenus ? sp., Anadoxides? sp. and Thoralaspis n. sp. A (Sdzuy, 1987), were considered to indicate the Lower Cambrian Ovetian regional Stage (Liñán, Perejón and Sdzuy, 1993). The stratigraphically lowermost occurrence of trilobites in the Borobia successions, assigned to Strenuaeva incondita, is in the lower part of the Ribota Formation (Fig. 2), whereas Lusatiops ribonatus and unidentified species of Andalusiana, Kingaspis, Redlichia and Strenuaeva have been reported elsewhere in the formation (Sdzuy, 1971a). The Ribota Formation was referred to the Marianian Stage (Liñán, Perejón and Sdzuy, 1993), and correlated with the Botoman regional Stage in Siberia (Liñán, Perejón et al., 1996) though no trilobite species in common occur. Similar faunal assemblage, with additional species of Micmacca aff. coloi and Kingaspis velatus, were recovered in the Huérmeda Formation which was also referred to the Marianian Stage in its upper portion (Liñán, Perejón and Sdzuy, 1993). Acritarch assemblages deriving from the interval with Strenuaeva incondita in the Ribota Formation and from several levels in the Huérmeda Formation are characteristic to the Heliosphaeridium dissimilareSkiagia ciliosa assemblage Zone that is recognized in Baltica, East Avalonia, Laurentia and Ibero-Armorica in northern Spain (MoczydXowska, 1991, in press; Palacios and Vidal, 1992; Vidal and Peel, 1993; Molyneux et al., 1996). The latter zone is time equivalent to the Holmia kjerulfi assemblage Zone in Baltica (Moczyd Xowska, 1991; Ahlberg and Bergström, 1993). The correlation of the Ribota Formation with the Holmia kjerulfi Zone is, however, primarily supported by the occurrence of the genus Strenuaeva which is diagnostic for this zone (Bergström and Gee, 1985; Ahlberg, 1985; Ahlberg et al., 1986; MoczydXowska, 1991). In the upper part of the Huérmeda Formation the trilobite species Protolenus $(H$.) termierelloides occurs (level Bo1-36, Fig. 2 ; Álvaro and Liñán, 1997). The upper part of the Daroca Formation contains the macrofossils Strenuaeva sp. and Pseudolenus sp. in the Borobia area (Fig. 4) (Liñán, pers. comm.), and an assemblage of trilobites "lacking olenellids", and yet undescribed, was found in other localities in the lower portion of the formation (Sdzuy, 1971a; Liñán, Perejón and Sdzuy, 1993). This faunal record was assumed to be characteristic for the lower Bilbilian Stage in the Iberian Chains. The acritarchs obtained from the lower Daroca Formation are indicative of the Volkovia dentifera-Liepaina plana assemblage Zone that is time equivalent to the Protolenus/Proampyx linnarssoni trilobite Zone (MoczydYowska, 1991; Palacios and Vidal, 1992; Vidal and Peel, 1993; Ahlberg and Bergström, 1993). The upper Daroca Formation in both studied successions yielded an acritarch assemblage that is restricted to the transitional Lower-Middle Cambrian interval elsewhere, and additionally Eliasum llaniscum, Celtiberium dedalinum and Retisphaeridium dichamerum which are age-diagnostic for the Middle Cambrian (Figs. 3, 5). Their lower stratigraphic ranges coincide with the base of the Middle Cambrian (Staplin et al., 1965; Fombella, 1977, 1978; MoczydXowska, in press). The abundance occurring Heliosphaeridium notatum has been established in a short stratigraphic interval encompassing the uppermost Lower Cambrian Protolenus Zone and the lowermost Middle Cambrian Acadoparadoxides oelandicus Superzone (Volkova et al., 1983; Hagenfeldt, 1989; Vidal and Peel, 1993; Moczydlowska, in press). The successive appearance of age-diagnostic species in the Borobia sections, first $H$. notatum in the lower Daroca Formation and then $E$. llaniscum with $C$. dedalinum followed by $R$. dichamerum in the upper Daroca Formation (Figs. 3, 5), records very accurately the Lower-Middle Cambrian boundary interval. The lowermost occurrence of E. llaniscum at the level of sample Bo1-40, (Figs. 2, 3) is taken to mark the base of the Middle Cambrian in the Borobia area. Previously, the Lower-Middle Cambrian boundary was recognized higher up in general stratigraphic succession of the Iberian Chains in the overlying Valdemiedes Formation at the level of the first record of Paradoxides (Acadoparadoxides) mureroensis Sdzuy, 1958 (Liñán and Gozalo, 1986; Liñán, Fernández-Nieto et al., 1993; Liñán, Perejón et al., 1996). Two faunal assemblages were distinguished in the Valdemiedes Formation, in its lower and upper portion, respectively. Several species of Hamatolenus, Alueva and Perrector? forming the "lower assemblage" of Valdemiedes, were interpreted to define the top of the Lower Cambrian Bilbilian Stage [Hamatolenus (H.) ibericus Zone; Liñán, FernándezNieto et al., 1993]. However, any of the mentioned genus have stratigraphic range limited to Lower Cambrian, neither in the Iberian Chains (see Liñán, Fernández-Nieto et al., 1993; Liñán, Perejón et al., 1996) nor elsewhere (Young et al., 1994). They occur also in Middle Cambrian and the $H$. (H.) ibericus species have only been referred in the Iberian Chains, thus per se, their use to recognize the top of Lower Cambrian is problematic.

Trilobite species of the "second assemblage" (e.g. stratigraphically younger) from the Valdemiedes Formation, consisting of Middle Cambrian age-diagnostic Paradoxides, among other less significant genera also included Hamatolenus (see full list of species in Liñán, Fernández-Nieto et al., 1993; Liñán, Villas et al., 1996), have been referred to the Leonian Stage at the base of Middle Cambrian. The proposed herein position of the Lower-Middle Cambrian boundary, based on the acritarch occurrence, is not in conflict with the trilobite record. It refines the boundary more precisely in this thick geological succession because of more abundant and dense distribution of largely facies independent phytoplanktonic microfossils that have been proven to be stratigraphically important elsewhere.

\section{SYSTEMATIC PALAEONTOLOGY}

The new recognized species of organic-walled microfossils are referred to the informal group Acritarcha Evitt, 1963, and they are treated as form-species because of the uncertain biological affinities (Evitt, 1963; Fensome et al., 1990). Some acritarch taxa are considered 


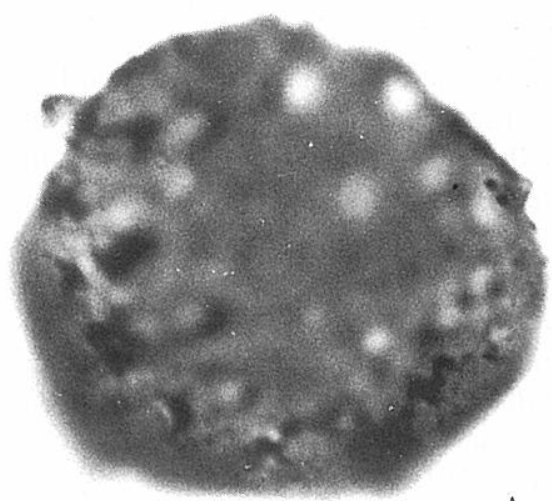

A

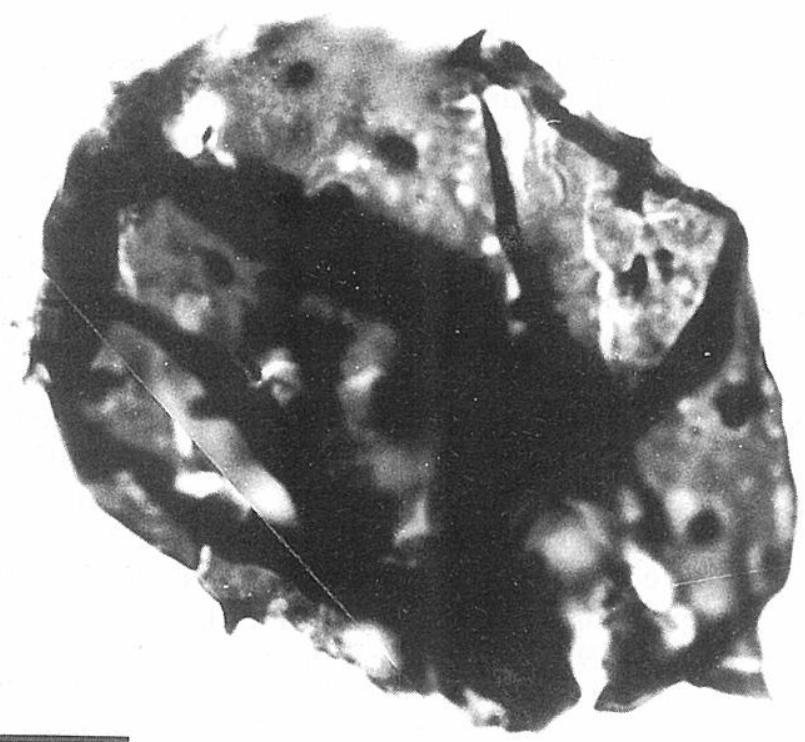

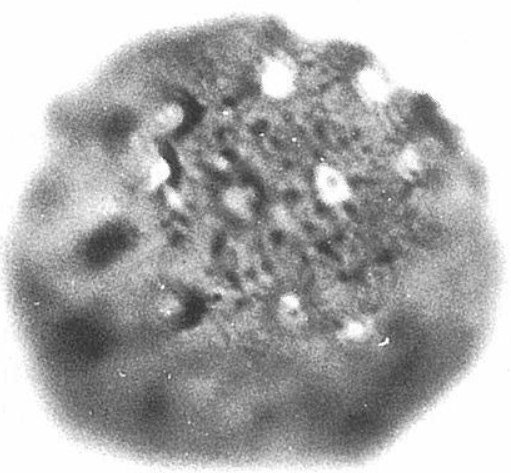

B

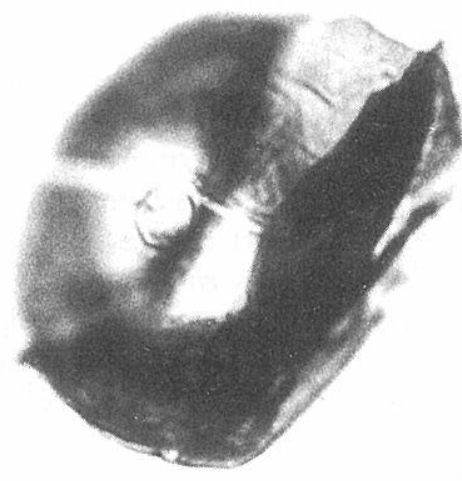

C

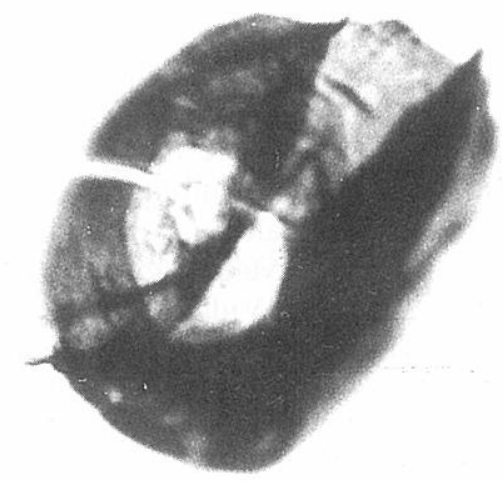

Figure 6. Scale bar in D corresponds to $10 \mu \mathrm{m}$ for all photomicrographs. • A, B. Celtiberium sp. A, at two different focuses showing the shape of processes on the vesicle outline (A), and the perforation of the vesicle wall (B). Borobia, Bo1A-9/2:F/34. C C, E. Leiosphaeridia bipylomifera $\mathrm{n}$. sp. Holotype at two focuses showing the upper surface of the vesicle with the minor pylome (C), and the lower surface with the major pylome (E). Borobia, Bo 1-39,/1:Y/33/4. • D. Lophosphaeridium conicum n. sp. Holotype. Borobia, Bo1 A-9/1:W/34/1.

to belong to various divisions of green algae (e.g. Prasinophyta and others), and they probably represent different stages of their life cycle (Tappan, 1980; Martin, 1993; Colbath and Grenfell, 1994). Acritarcheous microfossils may also include unidentified and/or extinct protists (Mendelson, 1993) or even copepod eggenvelopes (Van Waveren, 1994; Van Waveren and Marcus, 1993). The form-taxa described here are arranged in the alphabetic order since they are not conformed to the natural systematics. Microscopic slides containing holotypes and all figured specimens are kept in the collections of the Área de Paleontología, Universidad de Extremadura, Badajoz (UEB.PAL-). The location of specimens is given by the England Finder coordinates following the number of sample and microscopic slide. Photomicrographs have been taken under the Nikon light transmitted microscope with the immersion oil and interference contrast.

\section{Genus Celtiberium Fombella, 1977}

Type species: Celtiberium geminum Fombella, 1977; pp. 117-118; pl. 1, figs. 10, 11; fig. 1:9; Spain, Cantabrian Mountains, Oville Formation, Middle Cambrian.

\section{Celtiberium sp. A}

Figs. 6A, 6B

Material: A single, relatively well-preserved specimen.

Description: Organic-walled microfossil with spherical, single-layer vesicle, circular in outline, bearing few short processes. The processes are hemispheric-like or slightly conical with distal terminations closed and rounded; they are hollow inside and freely communicating with the internal cavity of the vesicle. The vesicle wall is psilate, thin, translucent and perforated by pores that are arranged around 
the processes. Only three processes are preserved on the visible vesicle surface but scares after those broken apart are clearly observable showing an even distribution of the processes on the vesicle. The vesicle diameter is $26 \mu \mathrm{m}$, process length and width is around $2 \mu \mathrm{m}$.

Present record: Clayey, organic-rich matrix of arkosic sandstone in the upper part of the Daroca Formation, previously referred to the upper Lower Cambrian (Liñán, Perejón and Sdzuy, 1993), and here regarded as the lowermost Middle Cambrian.

Genus Leiosphaeridia Eisenack, 1958, emend. Downie and Sarjeant, 1963

Type species: Leiosphaeridia baltica Eisenack, 1958; p. 8; pl. 2, fig. 5; Estonia, Ordovician (Ashgill).

Leiosphaeridia bipylomifera Palacios, n. sp. Figs. 6C, 6E

Holotype: Specimen UEB.PAL-Bo1-39,/1:Y/33/4 (Fig. 6C, $6 \mathrm{E})$.

Locus typicus: NE Spain, northwestern area of the Eastern Iberian Chain, Province of Soria, Borobia 1 section.

Stratum typicum: Alternating grey mudstone and finegrained sandstone in the lower part of the Daroca Formation, referred to the upper Lower Cambrian (Liñán, Perejón and Sdzuy, 1993), and here also regarded as the uppermost Lower Cambrian.

Derivatio nominis: From Latin bi (=two), and classical Greek $\pi \nu \lambda \omega \mu \alpha,-\alpha T O \sigma$ (=opening, pylome), referring to the two pylomes of the vesicle.

Material: Three relatively well-preserved specimens.

Diagnosis: The vesicle originally spherical, circular to ovoidal in outline after compression, with psilate wall surface, displaying two circular pylomes of different diameter that are located on the opposite sides of the vesicle.

Dimensions: $N=3$. The vesicle diameter ranges 20-26 $\mu \mathrm{m}$ (holotype $20 \times 26 \mu \mathrm{m}$ ), diameter of the bigger pylome is 8 to $11 \mu \mathrm{m}$, diameter of the smaller pylome is 4 to $5 \mu \mathrm{m}$.

Remarks: The outlines of pylomes are circular to semicircular due to the compaction and they might be seen as superimposed within each other. The compression folds are present on the vesicle surface. This is the first record of acritarch with two pylomes. Leiosphaerids with a single pylome were previously described from various occurrences (Martin and Dean, 1981).

Stratigraphic range and occurrence: As for the holotype, and SW Spain, Ossa-Morena Zone, Zafra area, La Albuera del Castellar section, La Lapa Formation, Vallehondo Member, uppermost Lower Cambrian.

Genus Lophosphaeridium Timofeev, 1959 ex Downie, 1963, emend. Lister, 1970

Type species: Lophosphaeridium rarum Timofeev, 1959 ex Downie, 1963; p. 630 (=Lophosphaeridium rarum Timofeev, 1959; p. 29; pl. 2, fig. 5; pl. 24, fig. 2); Russia, "Glauconitic beds", lower Ordovician.

\section{Lophosphaeridium conicum Palacios, n. sp. Fig. 6D}

Holotype: Specimen UEB.PAL-Bo1A-9/1:W/34/1 (Fig. 6D).

Locus typicus: NE Spain, northwestern area of the Eastern Iberian Chain, Province of Soria, Borobia 1A section.

Stratum typicum: Clayey, organic-rich matrix of arkosic sandstone in the upper part of the Daroca Formation, previously referred to the upper Lower Cambrian (Liñán, Perejón and Sdzuy, 1993), and here regarded as the lowermost Middle Cambrian.

Derivatio nominis: From Latin conus, $-i$ (=cone, apex), referring to the process shape.

Material: A single well-preserved specimen.

Diagnosis: The vesicle originally spherical, oval in outline after compaction, bears robust and evenly distributed short ornamentation elements in shape of thorns that are solid.

Dimensions: The vesicle diameter is $32 \times 42 \mu \mathrm{m}$, the thorn length is $3-4 \mu \mathrm{m}$ and their width at the base is $2-4 \mu \mathrm{m}$.

Stratigraphic range and occurrence: As for the holotype.

Genus Tubulosphaera Palacios, n. gen.

Type species: Tubulosphaera perfecta Palacios, n. sp.

Derivatio nominis: From Latin tubulus, $-i$ (=small tube), and sphara, $-\alpha$ (=sphere), referring to the spherical vesicle bearing processes tubular in shape.

Diagnosis: As for the type species.

Tubulosphaera perfecta Palacios, n. sp. Fig. 7

1990?Celtiberium sp.; Eklund, 25, fig. 9L.

Holotype: ?Celtiberium sp., Specimen LO 5945, slide Ög81-51:1/U39-3 (Collection of Lund University, Geology Department, Sweden), Eklund (1990: 25, fig. 9L). 

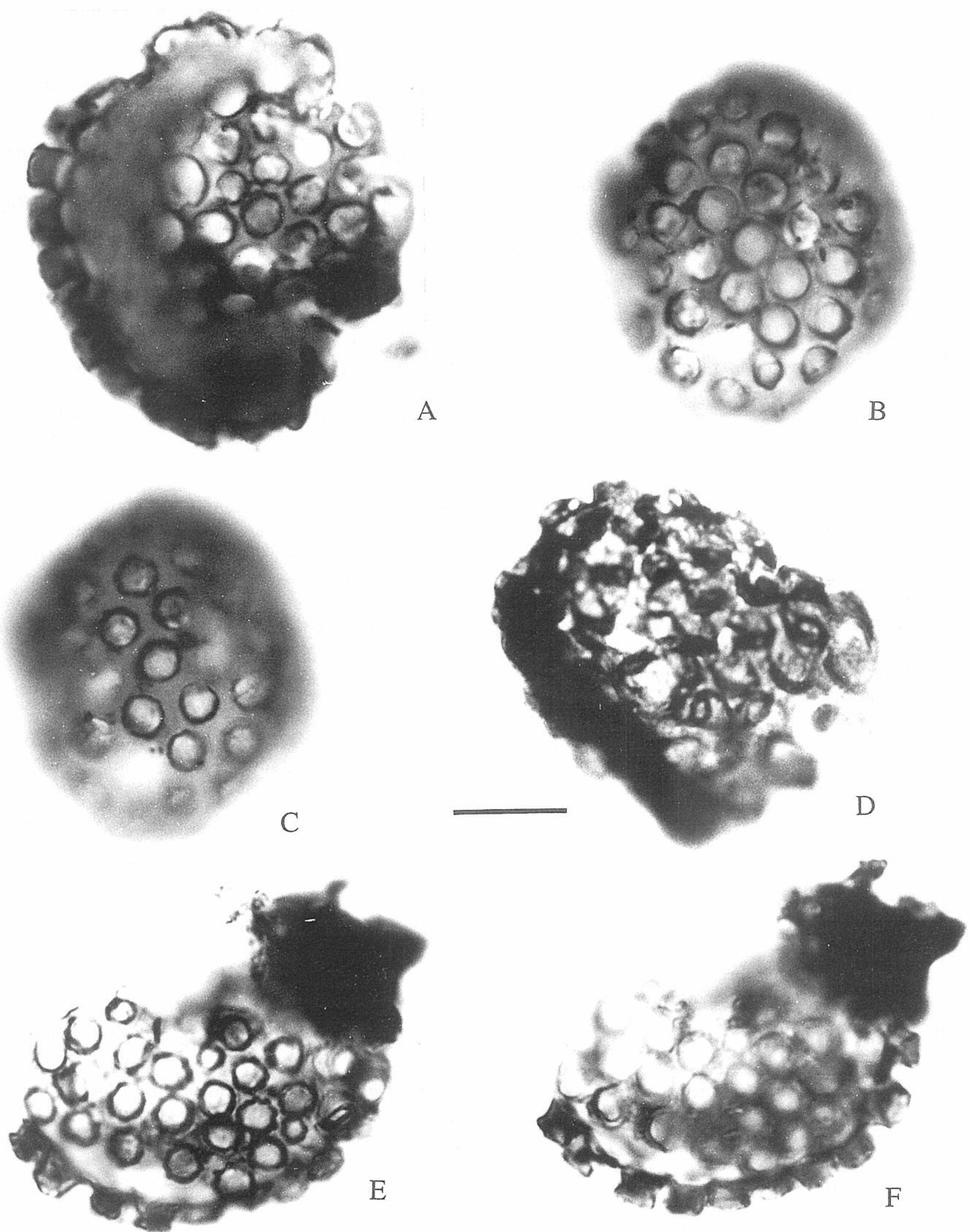

Figure 7. Tubulosphaera perfecta Palacios n. sp. Scale bar in D corresponds to $10 \mu \mathrm{m}$ for all photomicrographs. $\bullet$ A-C. Threedimensionally, exceptionally well preserved lectotype shown at various focus levels. La Albuera del Castellar, Zafra, C90-31/1:P/40. D. Poorly preserved specimen with collapsed edges of the process terminations. Borobia, Bo139,/2:M/38/4. • E, F. Fragment of the specimen with less well preserved processes displaying the initial taphonomic deformation of their regular tubular shape, as seen in the outline of the vesicle. The circular sections of the processes become also deformed and crenulated, as observed in the polar view on the vesicle surface. The same specimen at two focus levels. La Albuera del Castellar, Zafra, C90-31/1:Y/4 1. 

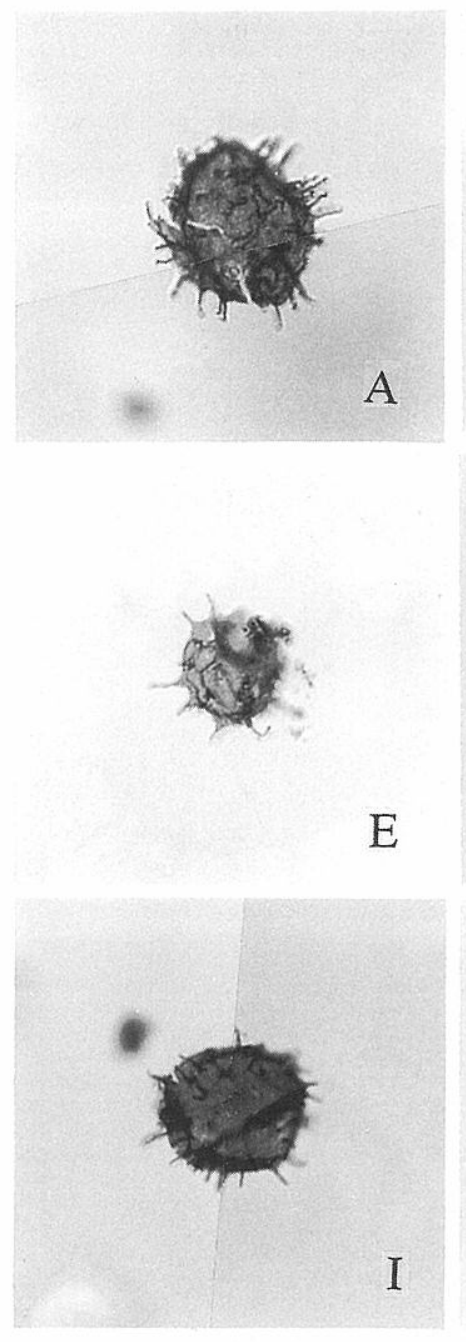

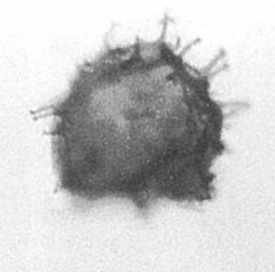

B

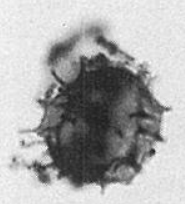

F

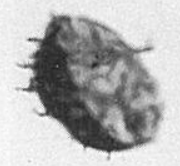

J
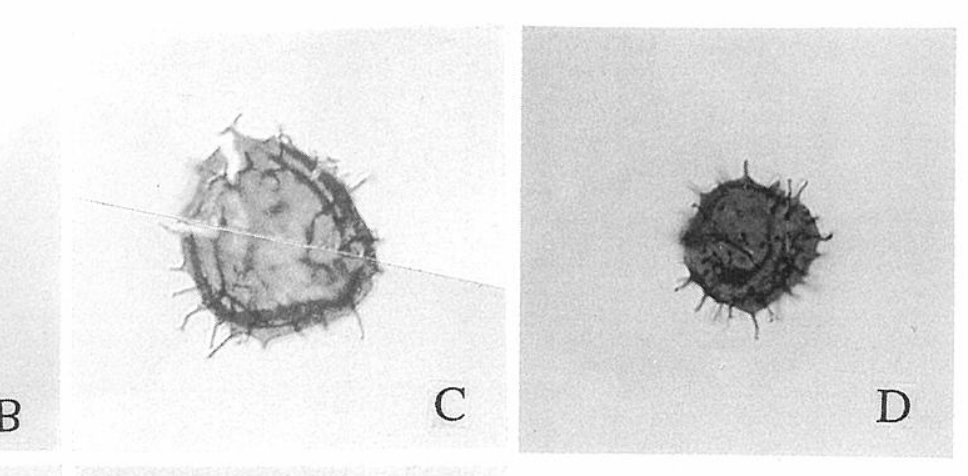

C

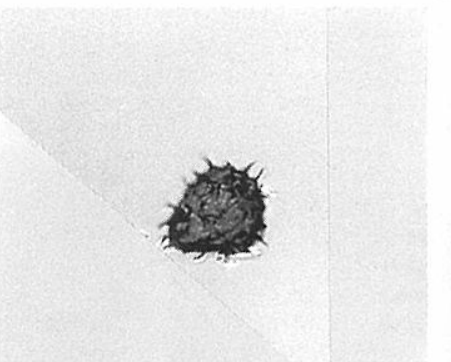

G
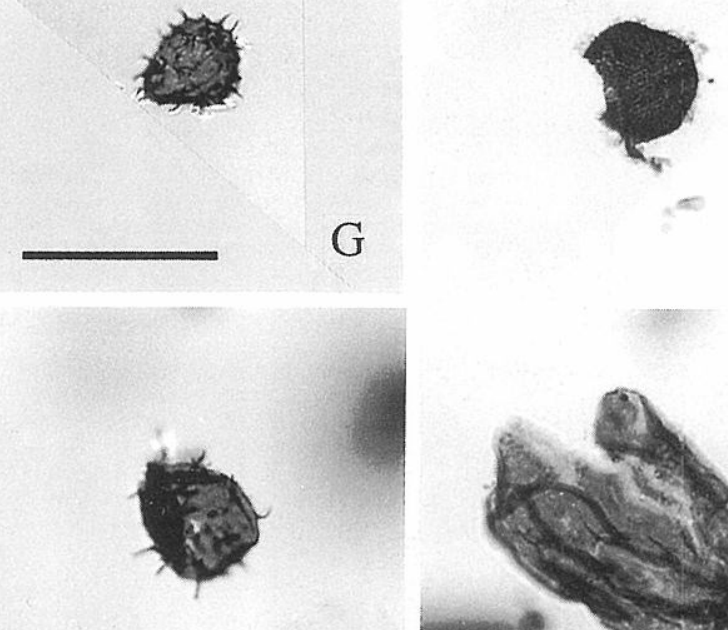

K

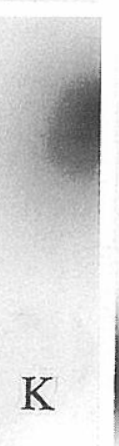

Figure 8. Scale bar in $\mathrm{G}$ corresponds to $20 \mu \mathrm{m}$ for all photomicrographs. • A-D. Heliosphaeridium notatum (Volkova, 1969) MoczydXowska, 1991. A. Borobia, Bo1-40,:Q/30/2. • B. Borobia, Bo1A-9/2:N/49/1. • C. Borobia, Bo139,/2:G/41/3. • D. Borobia, Bo1A-15:E/33/3. • E, F. Heliosphaeridium obscurum (Volkova, 1969) Moczydイowska, 1991. • E. Purujosa, Ribota Formation, Pu-4:T/34/1. • F. Borobia, Bo1A-9:O/49/3. • G. Asteridium spinosum (Volkova, 1969) MoczydXowska, 1991. Purujosa, Huérmeda Formation, Pu-25:Q/27/2. • H. Asteridium lanatum (Volkova, 1969) MoczydXowska, 1991. Borobia, Bo1-39-2:J/33/1/3. • I-K. Heliosphaeridium oligum (Jankauskas, 1976) MoczydXowska, in press. • I. Borobia, Bo1A-9:N/4911. • J. Borobia, Bo1A-6:S/44. • K. Borobia, Bo1A14:Z/35. • L. Eliasum llaniscum Fombella, 1977. Borobia, Bo1A-9:T/41.

Locus typicus: Sweden, Östergötland, Bårstad 2 borehole (Eklund, 1990: 20-21, fig. 1).

Stratum typicum: Glauconite sandstone in the informal "glauconite sandstone" member in the File Haidar Formation, the Bårstad 2 borehole at the depth of $48.5 \mathrm{~m}$ and $49.0 \mathrm{~m}$; Middle Cambrian, Eccaparadoxides insularis Zone (Eklund, 1990: 21-23).

Derivatio nominis: From Latin perfectus, - $a$, - um (=perfect, excellent, complete), referring to the very regular and exuberant morphology of the processes.

Material: Approximately hundred of well-preserved and three-dimensionally preserved specimens.

Diagnosis: Spherical vesicle bearing abundant and closely arranged regular processes in shape of tubes that may be slightly widened at the distal portion. The processes are distally closed and their terminations are flat or only slightly convex. The process cavities are freely connected with the vesicle interior. The distal edge of the processes is circular in outline that is visible in the polar view.

Dimensions: $N=50$. The overall vesicle diameter with processes ranges $25-45 \mu \mathrm{m}$, the vesicle diameter is $20-37$ $\mu \mathrm{m}$, the process length is $3-4 \mu \mathrm{m}$, the width of process bases is $2-4 \mu \mathrm{m}$, and the width of process terminations is $2-5 \mu \mathrm{m}$.

Remarks: The specimen described from Sweden under an open nomenclature as ?Celtiberium sp. (Eklund, 1990), is chosen herein to be the holotype of the new species. Though lacking the palaeontological description the Swedish specimen is very well preserved, illustrated 


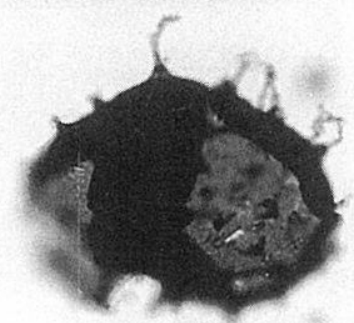

A

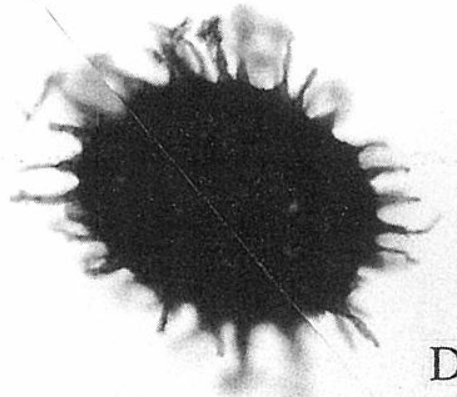

D
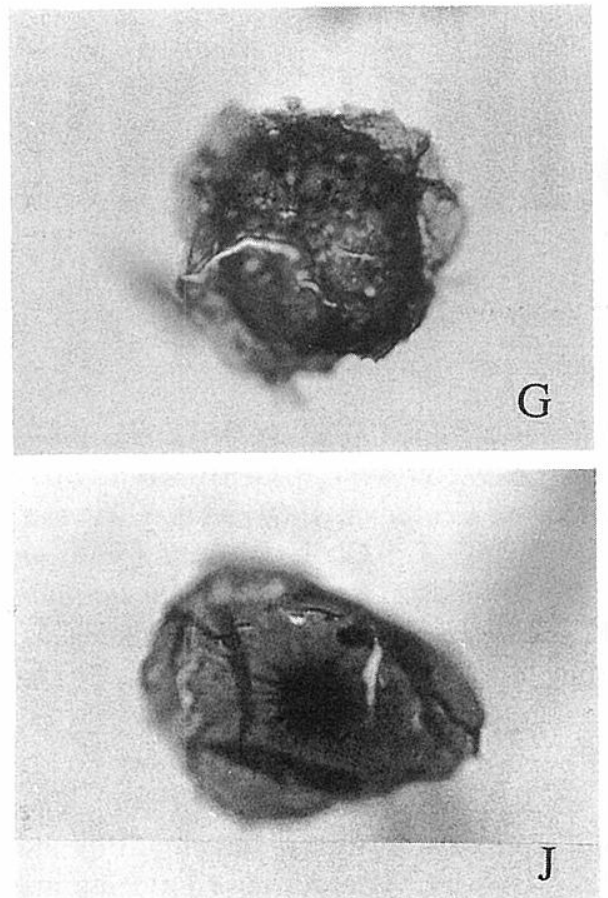
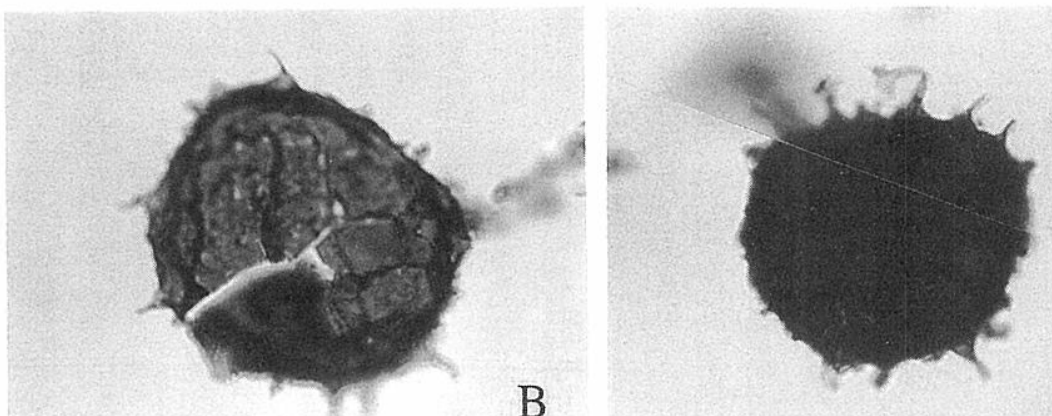

C
E
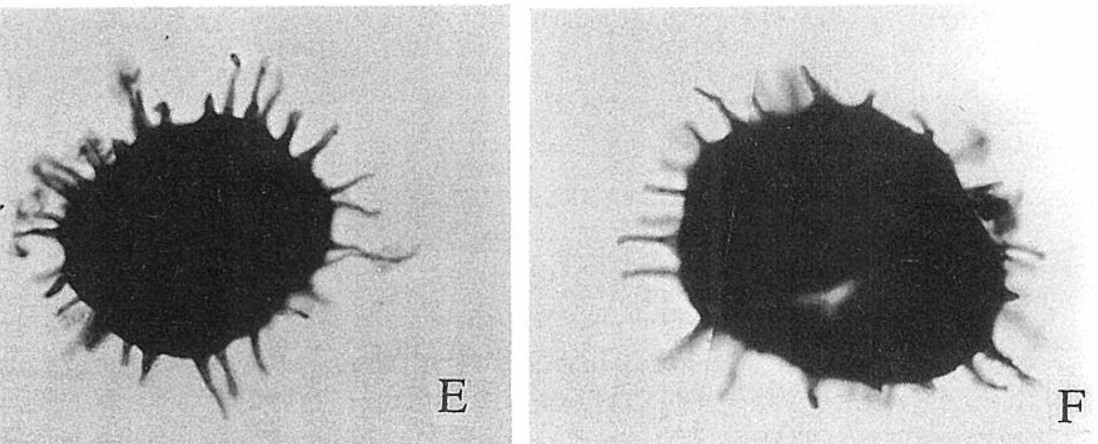

F

Figure 9. Scale bar in I corresponds to $25 \mu \mathrm{m}$ for all photomicrographs. - A-C, F. Skiagia ciliosa (Volkova, 1969) Downie, 1982. A. Borobia, Bo1-37/1:N/50. • B. Borobia, Bo1-92-5:Y/41. • C. Borobia, Bo1A-6:K/38. • F. Borobia, Bo1A13:M/31/3. • D, E. Skiagia compressa (Volkova, 1968) Downie, 1982. D. Borobia, Bo1A-2/1:G/37/1. • E. Borobia, Bo1A-3:M/31/3. • G. Granomarginata squamacea Volkova, 1968. Borobia, Bo1-92-5/2:U/44/2. • H. Comasphaeridium longispinosum Hagenfeldt, 1989. Borobia, Bo1-92-4/1:V/26/4. • I. Celtiberium dedalinum Fombella, 1978. Borobia, Bo1A-2/2:S/31. • J, K. Archaeodiscina umbonulata Volkova, 1968. • J. Borobia, Bo1-955/2:S/45/4. • K. Borobia, Bo1-95/2:M/39. • L. Retisphaeridium dichamerum Staplin, Jansonius and Pocock, 1965. Borobia, Bo1 $-40_{7}: \mathrm{G} / 39 / 1$.

and it is in the same dimensional range (Eklund, 1990: fig. 9L), and no doubt it represents the first record of the new species. The stratigraphic position of the holotype is defined by the occurrence of trilobites within the succession that are age-diagnostic for the basal Middle Cambrian Acadoparadoxides oelandicus Superzone in Scandinavia and East Avalonia (Eklund, 1990; Young et al., 1994; MoczydXowska, in press). 
Stratigraphic range and occurrence: As for the holotype in Sweden: Östergötland, Bårstad 2 borehole, File Haidar Formation, "oelandicus" beds (Eklund, 1990). And the present record comprising: NE Spain, Iberian Chains, Borobia area, lower portion of the Daroca Formation (sample 39/1), the upper part of Lower Cambrian (Liñán, Perejón and Sdzuy, 1993), and SW Spain, Ossa-Morena Zone, Zafra area, La Albuera del Castellar section, uppermost portion of the Vallehondo member of La Lapa Formation (upper part of Lower Cambrian) and lower portion of Playón beds, Middle Cambrian (Liñán et al., 1995; MoczydXowska et al., 1996) that are considered here the time equivalent to the Acadoparadoxides oelandicus Superzone (sample C-90-31/1:P/40).

\section{CONCLUSIONS}

The taxonomically diverse acritarch association from the Borobia successions provides a new mean for the biostratigraphic subdivision of the Lower Cambrian in the Iberian Chains and the recognition of the LowerMiddle Cambrian boundary. Three distinguished stratigraphically succeeding microfossil assemblages are characteristic for the Lower Cambrian Heliosphaeridium dissimilare-Skiagia ciliosa and Volkovia dentiferaLiepaina plana acritarch zones, and the informal lowermost Middle Cambrian acritarch assemblage. These zones correspond to the Holmia kjerulfi, Protolenus and Acadoparadoxides oelandicus trilobite zones respectively, and can be alternatively applied to define the chronostratigraphic equivalence of the strata from various faunal bioprovinces. The acritarch-based recognition of the Lower-Middle Cambrian boundary in the Daroca Formation, stratigraphically below the level previously assigned by trilobite faunas, may imply the need for re-evaluation of the boundary interval in other regions of the Iberian Peninsula. However, the newly proposed position for the boundary allows to correlate more precisely the geological successions between Iberia, Baltica and East Avalonia.

\section{ACKNOWLEDGEMENTS}

Our collaboration in studying Cambrian microfossils was established and inspired by the late Gonzalo Vidal. We sadly miss his brilliant companionship. This paper is a contribution to the projects: PB93-0410-CO1 (DGICYT), EIA95-06 (Junta de Extremadura y Fondo Social Europeo), and Palaeoecology of Cambrian Explosion (Swedish Natural Science Research Council, NFR to M. MoczydXowska).

We wish to thank Dr. R. Gozalo and Dr. A. Le Hérissé for useful suggestions and constructive criticism to this manuscript.

\section{REFERENCES}

Ahlberg, P. 1985. Lower Cambrian trilobite faunas from the Scandinavian Caledonides - a review. In: The
Caledonide Orogen - Scandinavia and Related Areas, Part 1. (Eds. D. G. Gee and B. A. Sturt). Wiley, Chichester, 339-346.

Ahlberg, P. and Bergström, J. 1993. The trilobite Calodiscus lobatus from the Lower Cambrian of Scania, Sweden. Geologiska Föreningens i Stockholm Förhandlingar, 115, 331-334.

Ahlberg, P., Bergström, J. and Johansson, J. 1986. Lower Cambrian olenellid trilobites from the Baltic Faunal Province. Geologiska Föreningens $i$ Stockholm Förhandlingar, 108, 39-56.

Álvaro, J. y Liñán, E. 1997. Nuevos datos acerca del Bilbiliense (Cámbrico Inferior terminal) en las Cadenas Ibéricas y su correlación con otras áreas. Revista Española de Paleontología, 12 (2), 277-280.

Alvaro, J., Liñán, E., Vennin, E. and Gozalo, R. 1995. Palaeogeographical evolution within a passive margin with syndepositional faulting: The Marianian deposits (Lower Cambrian) of the Iberian Chains (NE Spain). Neues Jahrbuch für Geologie und Paläontologie, Monatshefte, 1995 (9), 521-540.

Bergström, J. and Gee, D. 1985. The Cambrian in Scandinavia. In: The Caledonide Orogen - Scandinavia and Related Areas, Part 1. (Eds. D. G. Gee and B. A. Sturt). Wiley, Chichester, 247-271.

Colbath, G. K. and Grenfell, H. R. 1994. Review of biological affinities of Paleozoic acid-resistant, organicwalled eukaryotic algal microfossils (including "acritarchs"). Review of Palaeobotany and Palynology, 86, 287-314.

Cramer, F. H. and Díez Cramer, M. C. R. 1972. Acritarchs from the upper Middle Cambrian Oville Formation of León, northwestern Spain. Revista Española de Micropaleontología, 30, 39-50.

Di Milia, A., Ribecai, C. and Tongiorgi, M. 1989. Late Cambrian Acritarchs from the Peltura scarabaeoides Trilobite Zone at Degerhamn (Öland, Sweden). Palaeontographica Italica, 76, 1-56.

Downie, C. 1963. 'Hystrichospheres' (acritarchs) and spores of the Wenlock Shales (Silurian) of Wenlock, England. Palaeontology, 6, 625-652.

Downie, C. 1982. Lower Cambrian acritarchs from Scotland, Norway, Greenland and Canada. Transactions of the Royal Society of Edinburgh, 72, 257-285.

Downie, C. and Sarjeant, W. A. S., 1963. On the interpretation and status of some hystrichosphere genera. Palaeontology, 6, 83-96.

Eisenack, A. 1958. Tasmanites Newton 1875 und Leiosphaeridia n.g. als Gattungen der Hystrichosphaeridea. Palaeontographica, Abteilung A, 110, 1-19.

Eklund, K. 1990. Lower Cambrian acritarch stratigraphy of the Bärstad 2 core, Ostergötland, Sweden. Geologiska Föreningens $i$ Stockholm Förhandlingar, 112, 19-44.

Esnaola Gómez, J. M. y Martín Fernández, M. 1972. Mapa Geológico de España a escala 1:50.000. Hoja $n^{\circ} 351$ (Olvega). Primera edición. I.G.M.E., Madrid.

Evitt, W. R. 1963. A discussion and proposals concerning fossil Dinoflagellates, Hystrichospheres and Acritarchs. (U.S.) National Academy of Sciences Proceedings, 49, 158-164, 298-302. 
Fensome, R. A., Williams, G. L., Barss, M. S., Freeman, J. M. and Hill, J. M. 1990. Acritarchs and fossil Prasinophytes: and index to genera, species and infraspecific taxa. American Association of Stratigraphic Palynologists Contributions Series, 25, 1-771.

Fombella, M. A. 1977. Acritarcos de edad Cámbrico Medioinferior de la provincia de Léon. Revista Española de Micropaleontología, 9, 115-124.

Fombella, M. A. 1978. Acritarcos de la Formación Oville, edad Cámbrico Medio-Tremadoc, Provincia de Léon, España. Palinologia, Numero extraordinario, 1, 245-261.

Fombella, M. A. 1979. Palinología de la Formación Oville al Norte y Sur de la Cordillera Cantábrica, España. Palinología, 1, 1-14.

Gámez, J. A., Fernández-Nieto, C., Gozalo, R., Liñán, E., Mandado, J. y Palacios, T. 1991. Bioestratigrafía y evolución ambiental del Cámbrico de Borobia (Provincia de Soria, Cadena Ibérica Oriental). Cuadernos do Laboratorio Xeolóxico de Laxe, 16, 251-271.

Geyer, G. and Landing, E. 1995. The Cambrian of the Moroccan Atlas regions. In: Morocco '95. The LowerMiddle Cambrian standard of western Gondwana. Introduction, Field Guide, Abstracts, and Proceedings of the First Conference of the Lower Cambrian Stage Subdivision Working Group and I.G.C.P. Project 366 Ecological Aspects of the Cambrian Radiation. (Eds. G. Geyer and E. Landing). Beringeria, Special Issue 2, 746.

Geyer, G. and Palmer, A.R. 1995. Neltneriidae and Holmiidae (Trilobita) from Morocco and the problem of Early Cambrian intercontinental correlation. Journal of Paleontology, 69, 459-474.

Gozalo, R. 1995. El Cámbrico de las Cadenas Ibéricas. In: Memorias de las IV Jornadas Aragonesas de Paleontología: "La expansión de la vida en el Cámbrico". Libro homenaje al Prof. Klaus Sdzuy. (Eds. J. A. Gámez Vintaned and E. Liñán). Institución "Fernando el Católico", Zaragoza, 137-167.

Hagenfeldt, S. E. 1989. Middle Cambrian acritarchs from the Baltic Depression and south-central Sweden, taxonomy and biostratigraphy. Stockholm Contributions in Geology, 41, 177- 250.

Hernández Samaniego, A., Aragonés Valls, E., Olmo Zamora, P. del, Aguilar Tomás, M. J. y Ramírez del Pozo, J. 1980. Mapa Geológico de España a escala 1:50.000. Hoja $n^{\circ} 352$ (Tabuenca). Segunda seriePrimera edición. I.G.M.E., Madrid.

Landing, E. 1995. Upper Placentian-Branchian Series of mainland Nova Scotia (middle-upper Lower Cambrian): Faunas, paleoenvironments, and stratigraphic revision. Journal of Paleontology, 69, 475-495.

Liñán, E. 1984. Introducción al problema de la paleogeografía del Cámbrico de Ossa-Morena. Cuadernos do Laboratorio Xeolóxico de Laxe, 8, 283314.

Liñán, E. and Gámez-Vintaned, J. A. 1993. Lower Cambrian palaeogeography of the Iberian Peninsula and its relations with some neighbouring European areas. Bulletin de la Société géologique de France, 164 (6), 831-842.
Liñán, E. y Gozalo, R. 1986. Trilobites del Cámbrico inferior y medio de Murero (Cordillera Ibérica). Memorias del Museo Paleontológico de la Universidad de Zaragoza, 2, 104 pp.

Liñán, E. y Tejero, R. 1988. Las formaciones precámbricas del antiforme de Paracuellos (Cadenas Ibéricas). Boletín de la Real Sociedad Española de Historia Natural (Sección Geológica), 84 (1-2), 39-49.

Liñán, E., Gozalo, R., Gámez, J. A. y Álvaro, J. 1992. Las formaciones del Grupo Mesones (Cámbrico InferiorMedio) en las Cadenas Ibéricas. III Congreso Geológico de España y VIII Congreso Latinoamericano de Geología, Salamanca 1992, Actas, 1, 517-523.

Liñán, E., Fernández-Nieto, C., Gámez, J. A., Gozalo, R., Mayoral, E., Moreno-Eiris, E., Palacios, T. y Perejón, A. 1993. Problemática del límite Cámbrico Inferior-Medio en Murero (Cadenas Ibéricas, España). Revista Española de Paleontología, $\mathbf{n}^{\mathbf{0}}$ extraordinario, 26-39.

Liñán, E., Perejón, A. and Sdzuy, K. 1993. The LowerMiddle Cambrian stages and stratotypes from the Iberian Peninsula: a revision. Geological Magazine, 130, 817833.

Liñán, E., Gámez-Vintaned, J. A, Palacios, T., Alvaro, J., Gozalo, R., Mayoral, E., Moreno-Eiris, E., Perejón, A., Quesada, C. and Sanchez García, T. 1995. Day 2: September 21. The Cambrian of the Alconera Unit. In: XIII Geological Meeting on the West of the Iberian Peninsula, Characterization and evolution of the Neoproterozoic-Cambrian Basin on the Iberian Peninsula. Annual IGCP Project-319 Meeting: Global Paleogeography in the Upper Precambrian-Lower Cambrian. Regional IGCP Project-320 Meeting: Neoproterozoic Events and Resources. Pre-Conference Field Guide. Neoproterozoic-Cambrian Transect of Sierra Morena and Montes de Toledo. Spain. September, 19-24th. 1995. (Eds. M. D. Rodríguez Alonso and G. Alonso Gavilán). Signo, S. L., Salamanca, 9-21.

Liñán, E., Villas, E., Gámez Vintaned, J. A., Álvaro, J., Gozalo, R., Palacios, T. y Sdzuy, K. 1996. Síntesis paleontológica del Cámbrico y Ordovícico del Sistema Ibérico (Cadenas Ibéricas y Cadenas Hespéricas). Revista Española de Paleontología. $\mathbf{N}^{\circ}$ extraordinario, 21-32.

Liñán, E., Perejón, A., Sdzuy, K. and Gámez Vintaned, J. A. 1996. Part I. The Lower and Middle Cambrian Series of the Iberian Peninsula. I.2. The Lower Cambrian Series. In: II Field Conference of the Cambrian Stage Subdivision Working Groups. International Subcommission on Cambrian Stratigraphy. Spain, 13-21 September 1996. Field trip guide and abstracts (Eds. E. Liñán, J. A. Gámez Vintaned and R. Gozalo). Universidad de Zaragoza, Zaragoza, 9-16.

Lister, T. R. 1970. The acritarchs and chitinozoa from the Wenlock and Ludlow Series of the Ludlow and Millichope areas, Shropshire. Palaeontographical Society Monographs, 124, 1-100.

Lotze, F. 1961. Das Kambrium Spaniens. Teil I: Stratigraphie. Akademie der Wissenschaften und der Literatur, Abhandlungen der mathematischnaturwissenschaftlichen Klasse, 1961 (6), 283-498 (1216). [Traducción por J. Gómez de Llarena: El Cámbrico 
de España. Memorias del Instituto Geológico y Minero de España, 75, 1-256; año 1970.]

Martin, F. 1993. Acritarchs: A review. Biological Reviews, 68, 475-538.

Martin, F. and Dean, W. T. 1981. Middle and Upper Cambrian and Lower Ordovician acritarchs from Random Island, Eastern Newfoundland. Geological Survey of Canada, Bulletin, 343, 1-43.

Martin, F. and Dean, W. T. 1988. Middle and Upper Cambrian acritarch and trilobite zonation at Manuels River and Random Island, eastern Newfoundland. Geological Survey of Canada, Bulletin, 381, 1-91.

Mendelson, C. V. 1993. Acritarchs and prasinophytes. In: Fossil prokaryotes and protists. (Ed. J. H Lipps). Blackwell Scientific Publications, Boston, 77-104.

Mette, W. 1989. Acritarchs from Lower Paleozoic rocks of the western Sierra Morena, SW-Spain and biostratigraphic results. Geologica et Palaeontologica, 23, 1-19.

MoczydXowska, M. 1991. Acritarch biostratigraphy of the Lower Cambrian and the Precambrian-Cambrian boundary in southeastern Poland. Fossils and Strata, 29, 1-127.

MoczydXowska, M. In press. Cambrian acritarchs from Upper Silesia, Poland - biochronology and tectonic implications. Fossils and Strata.

MoczydXowska, M. and Vidal, G. 1992. Phytoplankton from the Lower Cambrian Ls formation on Bornholm, Denmark: biostratigraphy and palaeoenvironmental constraints. Geological Magazine, 129, 17-40.

MoczydXowska, M., Palacios, T. and Vidal, G. 1996. The Lower-Middle Cambrian boundary recognised by acritarchs at the margin of Gondwana: Sierra Morena and Iberian Chains, Spain and Upper Silesia, Poland. In: II Field Conference of the Cambrian Stage Subdivision Working Groups. International Subcommission on Cambrian Stratigraphy. Spain, 13-21 September 1996. Field trip guide and abstracts. (Eds. E. Liñán, J. A. Gámez Vintaned and R. Gozalo). Universidad de Zaragoza, Zaragoza, 107-109.

Molyneux, S. G., Le Hérissé, A. and Wicander, R. 1996. Palaeozoic phytoplankton. In: Palynology: Principles and Applications. Volume 2_Applications. (Eds. J. Jansonius and D. C. McGregor). American Association of Stratigraphic Palynologists Foundation, [printed in Salt Lake City], 492-529.

Palacios, T. 1993. Acritarchs from the Volcanosedimentary Group Playon Beds. Lower-Upper Cambrian, Sierra Morena, southern Spain. Terra Abstracts, 5, Abstract Supplement, $\mathbf{6}, 3$.

Palacios, T. and Vidal, G. 1992. Lower Cambrian acritarchs from northern Spain: the Precambrian-Cambrian boundary and biostratigraphic implications. Geological Magazine, 129, 421-436.

Palmer, A. R. 1996. Why is intercontinental correlation within the Lower Cambrian so difficult? In: II Field Conference of the Cambrian Stage Subdivision Working Groups. International Subcommission on Cambrian Stratigraphy. Spain, 13-21 September 1996. Field trip guide and abstracts. (Eds. E. Liñán, J. A. Gámez
Vintaned and R. Gozalo). Universidad de Zaragoza, Zaragoza, 114.

Palmer, A. R. and James, N. P. 1980. The Hawke Bay Event: A circum-Iapetus regression near the Lower Middle Cambrian boundary. In: The Caledonides in the U.S.A. (Ed. D. R. Wones). Dept. of Geological Sciences, Virginia Polytechnic Institute and State University Memoir, 2, 15-18.

Sdzuy, K. 1958. Neue Trilobiten aus dem Mittel Kambrium von Spanien. Senckenbergiana lethaea, 39 (3-4), 235253.

Sdzuy, K. 1961. Das Kambrium Spaniens. Teil II: Trilobiten. Akademie der Wissenschaften und der Literatur, Abhandlungen der mathematischnaturwissenschaftlichen Klasse, 1961 (7-8), 499-690 (217-408).

Sdzuy, K. 1968. Trilobites del Cámbrico Medio de Asturias. Trabajos de Geología, Universidad de Oviedo, 1 (1967), 77-133.

Sdzuy, K. 1971a. Acerca de la correlación del Cámbrico inferior de la Península Ibérica. I Congreso HispanoLuso-Americano de Geología Económica, Sección 1 Geología, 2, 753-768.

Sdzuy, K. 1971b. La subdivisión bioestratigráfica y la correlación del Cámbrico Medio de España. I Congreso Hispano-Luso-Americano de Geología Económica, Sección 1 Geología, 2, 769-782.

Sdzuy, K. 1972. Das Kambrium der acadobaltischen Faunenprovinz. Zentralblatt für Geologie und Paläontologie, Teil II, 1972 (1-2), 1-91.

Sdzuy, K. 1987. Trilobites de la base de la formación del Jalón (Cámbrico inferior) de Aragón. Revista Española de Paleontología, 2, 3-8.

Sdzuy, K., Liñán, E. and Gozalo, R. 1996. Part I. The Lower and Middle Cambrian Series of the Iberian Peninsula. I.3. The Middle Cambrian Series. In: II Field Conference of the Cambrian Stage Subdivision Working Groups. International Subcommission on Cambrian Stratigraphy. Spain, 13-21 September 1996. Field trip guide and abstracts. (Eds. E. Liñán, J. A. Gámez Vintaned and R. Gozalo). Universidad de Zaragoza, Zaragoza, 17-18.

Staplin, F. L., Jansonius, J. and Pocock, S.A.J. 1965. Evaluation of some Acritarchous Hystrichosphere Genera. Neues Jahrbuch für Geologie und Paläontologie, Abhandlungen, 123, 167-201.

Tappan, H. 1980. The Palaeobiology of Plant Protist. W. H.Freeman and Company, San Francisco. 1028 pp.

Timofeev, B. V. 1959. Drevnejshaja flora pribaltiki i ee stratigraficheskoe znachenie. [Ancient flora of the Baltic and its stratigraphic significance.] Trudy Vsesoyuznogo Neftjanogo Nauchno-Issledovatel'skogo Geologorazvedochnogo Instituta (VNIGRI), 129, 1-320.

Valenzuela, J. I., Gámez, J. A., Liñán, E. y Sdzuy, K. 1990. Estratigrafía de la región de Brea. Boletín de la Real Sociedad Española de Historia Natural (Sección Geológica), 85, 45-54.

Van Waveren, J. M. 1994. Chitinous palynomorphs and palynodebris representing crustacean exoskeleton remains from sediments of the Banda Sea (Indonesia). Scripta Geologica, 105, 1-25. 
Van Waveren, J. M. and Marcus, N. H. 1993. Morfology of Recent copepods egg envelopes from Turkey Point, Gulf of Mexico, and their implications for acritarch affinity. Special Papers in Palaeontology, 48, 111-124.

Vidal, G. 1981. Lower Cambrian acritarch stratigraphy in Scandinavia. Geologiska Föreningens i Stockholm Förhandlingar, 103, 183-192.

Vidal, G. 1985. Biostratigraphic correlation of the Upper Proterozoic and Lower Cambrian of the Fennoscandian Shield and the Caledonides of East Greenland and Svalbard. In: The Caledonide Orogen - Scandinavia and Related Areas, Part 1. (Eds. D. G. Gee and B. A. Sturt). Wiley, Chichester, 331-338.

Vidal, G. 1988. A palynological preparation method. Palynology, 12, 215-220.

Vidal, G. and MoczydXowska, M. 1996. Vendian-Lower Cambrian acritarch biostratigraphy of the central Caledonian fold belt in Scandinavia and the palaeogeography of the Iapetus-Tornquist seaways. Norsk Geologisk Tidsskrift, 76, 147-168.

Vidal, G. and Peel, J. S. 1993. Acritarchs from the Lower Cambrian Buen Formation in North Greenland. Grфnlands geologiske Unders $\phi$ gelse Bulletin, 164, 1-35.

Vidal, G., Palacios, T., Gámez-Vintaned, J. A., Díez Balda, M. A. and Grant, S. W. F. 1994. Neoproterozoic-early Cambrian geology and palaeontology of Iberia. Geological Magazine, 131, 729-765.
Volkova, N. A., Kiryanov, V. V., Piscun, L. V., Pashkyavichene, L. T. and Jankauskas, T. V. 1983. Plant microfossils. In: Upper Precambrian and Cambrian palaeontology of the East-European Platform. (Eds. A. Urbanek and A. Yu. Rozanov). Wydawnictwa Geologiczne, Warszawa, 5-46.

Welsch, M. 1986. Die Acritarchen der Höheren DigermulGruppe, Mittelkambrium bis Tremadoc, Ost-Finnmark, Nord-Norwegen. Palaeontographica, Abteilung B, 201, 1-109.

Young, T., Martin, F., Dean, W. T. and Rushton, A. W. A. 1994. Cambrian stratigraphy of St Tudwal's Peninsula, Gwynedd, northwest Wales. Geological Magazine, 131, 335-360.

Zang Wen-long. 1992. Sinian and Early Cambrian floras and biostratigraphy on the South China Platform. Palaeontographica, Abteilung B, 224, 75-119.

Zhuravlev, A. Yu. 1995. Preliminary suggestions on the global Early Cambrian Zonation. In: Morocco '95. The Lower-Middle Cambrian standard of western Gondwana. Introduction, Field Guide, Abstracts, and Proceedings of the First Conference of the Lower Cambrian Stage Subdivision Working Group and I.G.C.P. Project 366 Ecological Aspects of the Cambrian Radiation. (Eds. G. Geyer and E. Landing). Beringeria, Special Issue 2, 147160. 